\title{
Gene expression profiling of paired ovarian tumors obtained prior to and following adjuvant chemotherapy: Molecular signatures of chemoresistant tumors
}

\author{
SYLVAIN L'ESPÉRANCE ${ }^{1,4}$, ION POPA ${ }^{2,4}$, MAGDALENA BACHVAROVA $^{4}$, MARIE PLANTE $^{3,4}$, \\ NANCY PATTEN ${ }^{5}$, LIN WU $^{5}$, BERNARD TÊTU $^{2,4}$ and DIMCHO BACHVAROV ${ }^{1,4}$ \\ ${ }^{1}$ Department of Medicine, ${ }^{2}$ Division of Pathology, ${ }^{3}$ Department of Gynecologic Oncology, Faculty of Medicine, \\ Laval University, Québec G1K 7P4; ${ }^{4}$ Cancer Research Centre, Hôpital L'Hotel-Dieu de Québec, Centre Hospitalier \\ Universitaire de Québec, 9 rue McMahon, Québec G1R 2J6, Canada; ${ }^{5}$ Pharmacogenetics Department, \\ Roche Molecular Systems, Inc., 4300 Hacienda Drive, Pleasanton, CA 94588, USA
}

Received January 18, 2006; Accepted March 27, 2006

\begin{abstract}
Chemotherapy (CT) resistance in ovarian cancer is related to multiple factors, and assessment of these factors is necessary for the development of new drugs and therapeutic regimens. In an effort to identify such determinants, we evaluated the expression of approximately 21,000 genes using DNA microarray screening in paired tumor samples taken prior to and after CT treatment from 6 patients with predominantly advanced stage, high-grade epithelial ovarian cancer. A subset of differentially expressed genes was selected from all microarray data by initial filtering on confidence at $\mathrm{p}=0.05$, followed by filtering on expression level ( $\geq 2$-fold). Using these selection criteria, we found 121 genes to be commonly up-regulated and 54 genes to be down-regulated in the post-CT tumors, compared to primary tumors. Upregulated genes in post-CT tumors included substantial number of genes with previously known implication in mechanisms of chemoresistance (TOP2A, ETV4, ABCF2, PRDX2, COX2, COX7B, MUC1, MT3, MT2A), and tumorigenesis (SCGB2A2, S100A9, YWHAE, SFN, ATP6AP1, MGC5528, ASS, TACC3, ARHGAP4, SRA1; MGC35136, PSAP, SPTAN1, LGALS3BP, TUBA4, AMY2B, PPIA, COX1, GRB2, CTSL). Down-regulated genes in post-CT samples mostly included genes implicated in chemosensitivity (GRP, TRA1, ADPRTL1, TRF4-2), cell proliferation and cell cycle control (NGFRAP1, TPD52L1, TAX1BP1) and tumor suppression and apoptosis (SMOC2, TIMP3, AXIN1, CASP4, P53SCV). Additionally, gene clustering analysis revealed
\end{abstract}

Correspondence to: Dr Dimcho Bachvarov, CHUQ-Cancer Research Centre, Hôpital Hôtel-Dieu de Québec, 9 rue McMahon, Québec G1R 2J6, Canada

E-mail: dimtcho.batchvarov@crhdq.ulaval.ca

Key words: ovarian cancer, chemoresistance, second-look laparotomy, gene expression, DNA microarray the existence of two distinct expression signatures of chemoresistant tumors, which was further confirmed by assessment of some genetic (p53 gene mutation status) and clinical parameters (CT regimens). Our data suggest that intrinsic and acquired chemoresistant phenotypes of post-CT tumors may be attributed to the combined action of different factors implicated in mechanisms of chemoresistance, tumor invasion/progression and control of cell proliferation. This type of molecular profiling could have important clinical implications in resolving chemoresistance and the development of novel treatment strategies designed to prevent its emergence.

\section{Introduction}

Epithelial carcinoma of the ovary is characterized by presentation at an advanced stage and spreads primarily by an intraperitoneal route. An initial surgical approach is essential to proper staging of the disease process and to aggressive cytoreduction, which in turn improves response to chemotherapy and survival (1). Chemotherapy (CT) has had an increasingly important role in the effective treatment of ovarian cancer. Combination CT with taxol plus a platinum compound (carboplatin or cisplatin) is the current regimen of choice for the treatment of advanced epithelial ovarian cancer (2). A number of clinical issues, however, are unresolved including drug dosage and schedule, duration of treatment, and route of administration (3). Thus, although significant proportions of women respond to CT, the majority of responders ( $\sim 50-75 \%)$ eventually relapse at a median of 18-28 months (Du Bois A, et al, Proc ASCO 18: abs. 356, 1997; Ozols RF, et al, Proc ASCO 18: abs. 356, 1999). Treatment decisions at this juncture include supplementary chemotherapy with topotecan, doxorubicin, hormones, surgery, and experimental agents (4). Nonetheless, even with these additional treatments relapse rates remain high and most women with advanced ovarian cancer ultimately will die of their disease (5).

CT resistance in ovarian cancer is broad and encompasses diverse unrelated drugs, suggesting more than one mechanism of resistance. This topic has been the subject of intense 
research, and previous studies on ovarian cancer chemoresistance have investigated potential involvement of molecules involved in drug transport, apoptosis, DNA repair, and detoxification pathways (6-10). However for the majority of these factors, in vivo studies have failed to assess their clinical importance and to translate them into recommendations for specific therapies or prognosis in ovarian cancer patients (11-13). The above investigations suggest that CT resistance in ovarian cancer is related to multiple factors, and assessment of these factors is necessary for the development of new drugs and therapeutic regimens. In an effort to identify such determinants, we evaluated the expression of $\sim 21,000$ genes using DNA microarray screening in paired tumor samples taken prior to and following CT treatment from six ovarian cancer patients. For each patient, the gene expression profile of the post-CT tumor was compared to that of the corresponding primary 'chemonaïve' tumor sample. Our results provide the basis for further extended validation of specific markers that may be involved in the molecular mechanisms of clinical multidrug resistance in ovarian cancer.

\section{Patients and methods}

Patients and tissue specimens. Cancer tissues taken prior to (primary tumor tissue), and after adjuvant CT, were obtained for expression profiling analysis from 6 ovarian cancer patients. Paired tumor samples (pre- and post-CT) from 5 patients were obtained from the ovarian tumor bank at the Cancer Research Center at the Hôtel-Dieu de Québec Hospital, Québec, Canada, and paired tumor samples from one additional ovarian cancer patient were obtained from the ovarian tumor bank at the Department of Pathology, Vancouver General Hospital, British Columbia Cancer Agency, Vancouver, Canada. All tumors were histologically classified and graded according to the criteria defined by the World Health Organization. Tumor material from all patients was snapfrozen in liquid nitrogen within $1 \mathrm{~h}$ after surgery. Frozen sections were stained with hematoxylin and eosin; only samples that had more than $70 \%$ tumor cells were selected. All patients provided informed consent for voluntary participation before any procedures.

Gene expression analysis. Total RNA was isolated from frozen primary ovarian tumor samples using the TRIzol reagent (Invitrogen, Burlington, ON, Canada) and finally dissolved in RNase-free $\mathrm{H}_{2} \mathrm{O}$. Total RNA (5-10 $\left.\mu \mathrm{g}\right)$ was treated with DNase using the RNase-free DNase kit and RNeasy spin columns (Qiagen, Mississauga, ON). Total RNA treated with DNase was dissolved in RNase-free $\mathrm{H}_{2} \mathrm{O}$ to a final concentration of $0.2-0.5 \mu \mathrm{g} / \mu 1$. The quality of all RNA samples was examined by capillary electrophoresis using the Agilent 2100 Bioanalyzer (Agilent, Palo Alto, CA). Fluorescently labeled cRNA targets were generated from $0.5 \mu \mathrm{g}$ of total RNA in each reaction using the Fluorescent Linear Amplification Kit (Agilent) and 10.0 mM Cyanine 3- or 5-labeled CTP (Perkin-Elmer, Boston, MA), and following user's manual. Labeled cRNAs were purified using the RNeasy Mini Kit (Qiagen) and applied to the Human 1A (v2) Oligonucleotide Microarray (Agilent), containing 20,174 genes. For each patient, $1 \mu \mathrm{g}$ of cyanine-labeled cRNA from the primary
(pre-CT) tumor sample was mixed with equal amount of reverse-color cyanine labeled cRNA from the post-CT tumor sample. Hybridization and washing was performed using the in situ Hybridization Plus Kit (Agilent) and following the manufacturer's instructions. The arrays were scanned using a dual-laser DNA microarray scanner (Agilent). The data were then extracted from images by the Feature Extraction software 6.1 (Agilent). All microarray experiments were performed in duplicates.

Data analysis. The GeneSpring software (Agilent) was used to generate lists of selected genes and for different statistical and visualization methods. An Intensity-Dependent Normalization (known as Lowess normalization) was applied to correct for artifacts caused by non-linear rates of dye incorporation as well as inconsistencies of the relative fluorescence intensity between some red and green dyes. An initial gene list of 910 genes was created by Filtering on Confidence at $\mathrm{p}=0.05$ (using as measure of confidence the t-test $\mathrm{p}$-value, and as multiple testing correction - the Benjamini and Hochberg false discovery rate) to eliminate genes with unreliable measurements. Consecutive lists of differentially expressed genes derived from the 910 gene list were generated considering a 1.5- to 2-fold expression and using data from all independent experiments. Moreover, based on individual gene expression profiles, two distinct groups of patients were identified and the significant differences in expressed levels between the two groups were determined using 2-fold expression difference and the One-Way ANOVA test (Welch t-test) with p-value cutoff of 0.005. Comparisons of gene expression across the two groups were performed by Cluster Analysis using the Condition Tree Algorithm. The genes in the gene lists were classified according to their function using the Gene Ontology (GO SLIMS) classification system.

Semi-quantitative RT-PCR. Validation of differential gene expression was performed for a number of genes that were differentially expressed between the pre-CT and the post-CT tumor samples in all 6 ovarian cancer patients. The actinregulatory protein cap $\mathrm{G}$ gene (CAPG) displayed no change in expression levels in all tumor samples analyzed and was used as an internal standard. Primers were designed for these loci with the sequences freely available from the Entrez Nucleotide database and the Primer3 algorithm for primer design (http://www-genome.wi.mit.edu/cgi-bin/primer/ primer3_www.cgi). After determination of correct cycling parameters in order to allow measurements in the exponential PCR phase, a duplex semi-quantitative RT-PCR (sqRT-PCR) was performed as previously described (14). Briefly, $2 \mu \mathrm{g}$ of DNase I-treated RNA was reverse-transcribed into first-strand cDNA in a $20-\mathrm{ml}$ reaction using the MMLV (Moloney-murineleukaemia virus) RT (Invitrogen). cDNA templates $(0.5 \mu \mathrm{g})$ were amplified in a 50- $\mu 1$ reaction containing 2.5 pmol of each primer, $200 \mathrm{mM}$ dNTPs and 1.5 units of Taq polymerase (Invitrogen). Each PCR reaction contained two pairs of PCR primers needed for the simultaneous amplification of two PCR fragments: one belonging to the gene of interest and the other representing the CAPG PCR fragment, used as an internal standard. The samples were initially denatured for $3 \mathrm{~min}$ at $94^{\circ} \mathrm{C}$ and then submitted to $21-25$ cycles of PCR 
Table I. Patient clinicopathological characteristics.

\begin{tabular}{|c|c|c|c|c|c|c|c|}
\hline Patient & Age & HT & Grade & Stage & $\begin{array}{c}\text { TTR } \\
\text { (months) }\end{array}$ & $\begin{array}{l}\text { Period between last CT } \\
\text { and 2nd LAP (months) }\end{array}$ & LFU \\
\hline VOA149 & 57 & SPAC & 3 & IIIC & 8 & 8 & DOD \\
\hline OV-111 & 65 & SPAC & 3 & IV & 13 & 13 & DOD \\
\hline OV-234 & 49 & $\mathrm{CCC}$ & NA & IC & 17 & 17 & DOD \\
\hline OV-86 & 63 & SPAC & 3 & IIIC & 9 & 40 & LFU \\
\hline OV-113 & 42 & SPAC & 2 & IV & 16 & 3 & DOD \\
\hline OV-118 & 41 & SPAC & 1 & IIIC & 5 & 12 & LFU \\
\hline
\end{tabular}

HT, histological type; SPAC, serous papillary adenocarcinoma; CCC, clear cell carcinoma; CT, chemotherapy; TTR, time to recurrence following initial CT; LAP, laparotomy; LFU, lost from follow-up; DOD, died of disease; NA, not applicable.

(45 sec at $94^{\circ} \mathrm{C}, 45 \mathrm{sec}$ at $58-62^{\circ} \mathrm{C}$ and $75 \mathrm{sec}$ at $72^{\circ} \mathrm{C}$ ) followed by a 10 -min final elongation step at $72^{\circ} \mathrm{C}$. One-fifth of each PCR was run on a $1.5-2 \%$ agarose gel in $1 \mathrm{X}$ TBE buffer (45 mM Tris/borate/1 mM EDTA) and the gel was documented using the AlphaImager 2200 gel documentation system (Alpha Innotech, San Leandro, CA) and analyzed using the publicly available NIH ImageJ $1.33 \mathrm{u}$ program (http:// rsb.info.nih.gov/ij). Each expression value was calculated as a relative ratio between the signal of the specific PCR fragment and that of the internal standard. The data obtained were statistically analyzed by the unpaired t-test using the GraphPad InStat Software version 3.06 (San Diego, CA).

p53 gene mutation analysis. p53 mutation analysis was performed with genomic DNA extracted from all pre- and postCT tumors using the AmpliChip p53 Test, a product which is currently under development at Roche Molecular Systems, Inc. The AmpliChip p53 Test is based on the microarray technology and is designed to re-sequence the coding region of the p53 gene and query for the presence of sequence alterations through comparative analysis of the hybridization pattern of a series of probes from sample DNA to wt reference DNA. Briefly, the test uses AmpliChip p53 microarrays, containing over 220,000 different oligonucleotide probes that are synthesized on a glass surface to analyze both sense and antisense strands of an amplified target DNA specimen. Upon PCR amplification and labeling of the p53 exons from specimen or reference samples, the biotin-labeled p 53 amplicon fragments are hybridized to the AmpliChip p53 microarrays. The hybridized microarrays are washed and stained with a streptavidin-conjugated fluorescent dye (phycoerythrin) and are consecutively scanned by an Affymetrix GeneChip Scanner 3000Dx using a laser that excites the fluorescent label bound to the hybridized p53 amplicon fragments. The amount of emitted light is proportional to bound target DNA at each location on the probe microarray. Data analysis is performed by the GeneChip Operating Software (GCOS) and the AmpliChip p53 Data Analysis Software which uses p53 specific algorithms to analyze the intensity patterns of DNA samples, compare to the wt reference DNA sample and determine the sequence of 553 gene in the sample.

\section{Results}

Gene expression profiling. Our study included 6 patients with predominantly advanced stage, high-grade epithelial ovarian cancer, from whom both pre- and post-CT tumor specimens were available. The clinicopathological characteristics of these patients are presented in Table I. All 6 patients have undergone primary debulking surgery followed by standard platinum/ taxol combination therapy. They have displayed different time to recurrence intervals (TTR) after initial CT (7-17 months; Table I) that are essentially below the median progressionfree interval (20-22 months) estimated for ovarian cancer patients receiving similar initial treatment $(15,16)$. The period between the last CT treatment and the second-look laparotomy was quite variable for the 6 patients, ranging between 3-40 months (Table I).

In order to look for molecular signatures of chemoresistant ovarian tumors, we performed pairwise gene expression comparison between pre- and post-CT tumor samples obtained from the same patient, as all microarray experiments were carried out in replicates. A subset of differentially expressed genes was selected from all microarray data by initial filtering on confidence at $\mathrm{p}=0.05$, followed by filtering on expression level ( $\geq 2$-fold). Using these selection criteria, we found 121 genes to be commonly up-regulated and 54 genes to be downregulated in the post-CT tumors, compared to that of the primary tumors. Functional classes of the 121 up-regulated genes mainly include metabolism (14\%), signal transduction $(13 \%)$, tumor progression $(12 \%)$, chemoresistance $(7 \%)$, regulation of transcription $(7 \%)$, cell growth $(6 \%)$, protein biosynthesis and modification (6\%), transport $(5 \%)$, cellular structural component (4\%), development (3\%), apoptosis $(1 \%)$, DNA repair $(1 \%)$; the remainder $(21 \%)$ have unknown function. Table IIA shows list of selected genes that were up-regulated in the post-CT tumors. As seen from Table IIA, there is substantial number of up-regulated genes with previously shown implication in mechanisms of chemoresistance, including ovarian cancer chemoresistance (TOP2A, ETV4, ABCF2, PRDX2, COX2, COX7B, MUC1, MT3, MT2A), as well as genes linked with tumor progression and ovarian malignancy (SCGB2A2, S100A9, YWHAE, SFN, 
Table II. List of selected differentially expressed genes (2-fold $\left.{ }^{\mathrm{a}} ; \mathrm{p}=0.05\right)$ in paired samples of post-CT ovarian tumors as compared to corresponding primary tumors.

A, Selected up-regulated genes in the post-CT tumors

Fold change Gene name Description

Functions

4.67 SCGB2A2 Secretoglobin, family 2A, member $2 \quad$ Involved in breast tumorigenesis

3.74 S100A9 S100 calcium binding protein A9

3.42 TOP2A Topoisomerasse (DNA) II alpha

2.89 $\quad$ YWHAE 3-3 epsilon protein

2.89 ETV4 variant gene 4

2.76 SFN 14-3-3 sigma protein

2.62 PPP2R4 Protein phosphatase 2A, subunit B'

2.61 ATP6AP1 ATPase, $\mathrm{H}+$ transporting

$2.54 \quad$ MGC5528

Defective in sister chromatid cohesion 1

$2.52 \quad \mathrm{ABCF} 2$

$2.45 \quad$ PRDX2

$2.39 \quad$ ASS

2.39 H1F0

2.36 TACC3

ATP-binding cassette, sub-family F-2

Peroxiredoxin 2

Argininosuccinate synthetase

H1 histone family, member 0

Transforming, acidic coiled-coil

containing protein 3

$2.31 \quad \mathrm{COX} 2$

Cytochrome c oxidase II

2.30

ARHGAP4

Rho GTPase activating protein 4

2.27

SRA1

2.23

APTX

Steroid receptor RNA activator 1

2.22

MGC35136

Aprataxin

2.21

PSAP

Hypothetical protein MGC35136

Prosaposin

2.21

SPTAN1

2.18

LGALS3BP

Spectrin, alpha

2.14

TUBA4

2.11

PHB

2.10

IRF3

2.06

AMY2B

2.06

PPIA

2.06

COX1

2.05

COX7B

2.02

CD47

2.02

GRB2

2.01

TP53I11

1.85

MUC1

1.68

CTSL

Lectin 3 binding protein

Tubulin, alpha 4

Prohibitin

Interferon regulatory factor 3

Amylase, alpha 2B; pancreatic

Peptidylprolyl isomerase A

Cytochrome c oxidase I

Cytochrome c oxidase subunit VIIb

CD47 antigen

Growth factor receptor-bound protein 2

Tumor protein $\mathrm{p} 53$ inducible protein 11

Mucin 1, transmembrane

Cathepsin L

Metallothionein 3

Metallothionein 2A

$1.51 \quad$ MT2A

$\mathrm{UV}$ radiation resistance associated gene

Inflammation; ovarian tumor progression $(42)^{\mathrm{b}}$

Ovarian cancer chemoresistance $(22,30,31)$

Cell cycle control; tumor progression

Ovarian cancer cisplatin resistance $(34,35)$

Cell cycle control; ovarian tumor progression (43)

Negative regulator of cell proliferation

Proton transport; tumorigenesis

Chromosomal instability; cancer progression

Ovarian cancer chemoresistance $(36,37)$

Chemoresistance and radioresistance (39-41)

Arginine and NO synthesis; tumor progression (44)

Negative regulator of cell proliferation

Tumorigenesis; ovarian cancer marker (45)

Ovarian cancer chemoresistance $(23,24)$

Tumor neovascularization

Ovarian tumorigenesis (46)

DNA repair; genotoxic stress

Cancer therapy; angiogenesis

Lipid transport; tumorigenesis

Cytoskeleton; tumorigenesis

Tumor marker; tumorigenesis

Tumorigenesis

Cell growth; DNA metabolism

Tumor suppressor

Carbohydrate metabolism; tumorigenesis

Protein folding; tumor progression

Inflammation; ovarian cancer marker (47-49)

Expressed specially in post-CT breast tumors (25)

Integrin-mediated signaling; apoptosis

Signal transduction; tumorigenesis

Cell proliferation; response to stress

Ovarian cancer chemotherapy marker

Tumor invasion and metastasis

Metal ion homeostasis; chemoresistance

Copper ion homeostasis; chemoresistance

DNA repair

$\mathrm{B}$, Selected down-regulated genes in the post-CT tumors

Fold change Gene name Description

Functions

\begin{tabular}{lll}
\hline-4.65 & SMOC2 & SPARC related modular Ca binding 2 \\
-4.00 & FHL2 & Four and a half LIM domains 2 \\
-3.55 & TIMP3 & Tissue inhibitor of metalloproteinase 3 \\
-2.62 & S100B & S100 calcium binding protein, beta \\
-2.47 & GRP & Gastrin-releasing peptide
\end{tabular}

Ovarian tumor suppression

Ovarian tumor marker

Inhibition of metastasis

Metabolism, melanoma marker

Signal transduction, drug sensitivity 
Table II. Continued.

\begin{tabular}{llll}
\hline $\begin{array}{l}\text { B } \text { Selected down-regulated genes in the post-CT tumors } \\
\text { Fold change }\end{array}$ & \multicolumn{1}{c}{$\begin{array}{c}\text { Description } \\
\text { Gene name }\end{array}$} & \multicolumn{1}{c}{ Functions } \\
\hline-2.36 & SERPING1 & $\begin{array}{l}\text { Serine (or cysteine) proteinase inhibitor, } \\
\text { clade G member 1 }\end{array}$ & $\begin{array}{l}\text { Complement activation, putative marker in } \\
\text { cervical cancer }\end{array}$ \\
-2.29 & NGFRAP1 & NGFR associated protein 1 & Receptor activity, cell proliferation \\
-2.29 & FMOD & Fibromodulin & Extracellular matrix, tumor-associated antigen \\
-2.25 & PLAT & Plasminogen activator, tissue & Ovarian tumor marker \\
-2.16 & TPD52L1 & Tumor protein D52-like 1 & Cell proliferation \\
-2.05 & CSF1R & CSF 1 receptor & Receptor, ovarian cancer marker \\
-1.68 & TRA1 & Tumor rejection antigen 1 & Response to stress; chemosensitivity \\
-1.61 & ADPRTL1 & PARPL & Protein ADP-ribosylation; chemosensitivity \\
-1.58 & AXIN1 & Axin 1 & Signal transducer; tumor suppressor \\
-1.58 & TAX1BP1 & Tax1 binding protein 1 & Cell proliferation and cell cycle control \\
-1.57 & CASP4 & Caspase 4 & Apoptosis \\
-1.56 & TFR4-2 & Topoisomerase-related protein & Camptothecin sensitivity \\
-1.52 & P53SCV & HSPC132 (p53-inducible) & Apoptosis \\
\hline
\end{tabular}

${ }^{a}$ The above gene lists contain some additional genes with lower expression values (ranging between 1.5- to 2-fold), which are functionally relevant to tumor biology and response to treatment. ${ }^{\text {b }}$ The table contains selected references supporting the involvement of certain genes in mechanisms of chemoresistance and ovarian tumorigenesis.

ATP6AP1, MGC5528, ASS, TACC3, ARHGAP4, SRA1; MGC35136, PSAP, SPTAN1, LGALS3BP, TUBA4, AMY2B, PPIA, COX1, GRB2, CTSL). Several genes involved in negative regulation of cell proliferation (PPP2R4, H1F0, PBP, TP53I11) and DNA repair (APTX, UVRAG) were also found to be up-regulated.

Fifty-four genes were subject to at least 2-fold downregulation in the post-CT tumors. Major classifications of these genes comprise immune response (15\%), regulation of transcription (14\%), metabolism (13\%), signal transduction (11\%), development (10\%), tumor progression (8\%), cellular structural component $(7 \%)$, transport $(6 \%)$, cellular growth $(3 \%)$, and unknown function (13\%). Table IIB shows list of selected genes that were down-regulated in the post-CT tumors. This list includes genes implicated in chemosensitivity (GRP, TRA1, ADPRTL1, TRF4-2), cell proliferation and cell cycle control (NGFRAP1, TPD52L1, TAX1BP1), tumor suppression and apoptosis (SMOC2, TIMP3, AXIN1, CASP4, P53SCV). Interestingly, several tumor (including ovarian tumor) markers (FHL2, S100B, PLAT, SERPING1, FMOD, CSF1R) were found to be down-regulated in the post-CT samples.

Supplemental data Table I shows the complete list of differentially expressed genes in the post-CT ovarian tumors as compared to that of the primary tumors.

Confirmation of the expression measurements. To validate microarray results, we arbitrarily selected 13 up-regulated genes and quantified their expression by sqRT-PCR in the available pre- and post-CT tumor samples, Table III summarizes the gene expression measurements of all validated genes. We found that both methods (microarray analysis and sqRT-PCR) detected similar patterns for the 13 up-regulated genes selected for validation. Mean expression values were positive for all 13 genes and significantly positive $(\mathrm{p} \leq 0.05)$ for 8 of 13 genes.

Identification of two distinct pre/post-CT expression profiles: possible link with p53 mutation status and/or CT treatment regimens. Surprisingly, upon examination of the individual gene expression profiles (pre- and post-CT) of the 6 ovarian cancer patients studied we have detected two distinct types of gene expression profiles, unraveling the possible existence of two separate groups each including 3 patients: Group 1 including patients VOA149, OV-111 and OV-234, and Group 2 including patients OV-86, OV-113 and OV-118. This observation was further confirmed by cluster analysis. First, we selected a subset of candidate genes by filtering on signal intensity (2-fold) to eliminate genes with uniformly low expression or genes whose expression did not vary significantly across the samples, retaining 3,167 genes. One-way ANOVA parametric test (Welch t-test; variances not assumed equal) was further used to select discriminatory genes. t-tests with p-value cutoff of 0.005 selected 264 genes for which expression differed between the 2 groups. Clustering analysis based on the 264 gene list was performed using the standard Condition Tree algorithm provided in GeneSpring and revealed formation of two major cluster groups (Fig. 1). The 264 gene list is presented in Supplemental data Table II.

One hundred and twenty-one genes from the 264-genes list were respectively up-regulated in Group 1 tumors and down-regulated in Group 2 tumors. Major classifications of these genes include regulation of transcription, protein biosynthesis, cell proliferation and metabolism. Genes downregulated in Group 1 tumors and up-regulated in Group 2 
Table III. Correlation of mRNA expression data from the training set with sqRT-PCR derived values.

\begin{tabular}{lccccc}
\hline Gene name & $\begin{array}{c}\text { Fold change } \\
\text { (microarrays })\end{array}$ & $\begin{array}{c}\text { Mean value in } \\
\text { pre-CT tumors }\end{array}$ & $\begin{array}{c}\text { Mean value in } \\
\text { post-CT tumors }\end{array}$ & $\begin{array}{c}\text { Ratio } \\
\text { post-CT/pre-CT }\end{array}$ \\
\hline TOP2A & 3.420 & 0.3395 & 0.6056 & 1.7838 & 0.0079 \\
ATP6AP1 & 2.608 & 0.7968 & 1.1537 & 1.4479 & 0.1119 \\
PRDX2 & 2.446 & 1.1230 & 1.5670 & 1.3954 & 0.0389 \\
ASS & 2.390 & 0.7469 & 1.080 & 1.4460 & 0.1352 \\
COX2 & 2.310 & 1.5722 & 4.7160 & 2.9996 & 0.0471 \\
PPP2R4 & 2.264 & 0.1113 & 0.2440 & 2.1923 & 0.1022 \\
PPIA & 2.060 & 0.4370 & 0.4939 & 3.1302 & 0.3495 \\
COX1 & 2.060 & 1.2241 & 2.9063 & 1.1604 & 0.0476 \\
COX7B & 2.051 & 0.5938 & 1.0560 & 1.7784 & 0.5394 \\
MUC1 & 1.849 & 0.7038 & 2.1220 & 3.0151 & 0.0159 \\
CTSL & 1.683 & 1.1500 & 2.4950 & 2.1696 & 0.0002 \\
MT2A & 1.505 & 0.2349 & 0.5782 & 2.4615 & 0.0344 \\
UVRAG & 1.480 & & & 0.0470 \\
\hline
\end{tabular}

${ }^{a}$ Mean value was calculated as the mean expression value for given marker in all pre- and post-CT tumor samples.

Table IV. Selected functional categories of differentially expressed genes (2-fold; $\mathrm{p}=0.005)$ that are specific for Group 1 , or Group 2 post-CT ovarian tumors.

A, Specific sets of genes up-regulated in Group 1 and down-regulated in Group 2

Gene symbol

Function

TERF1, OS-9, TACC3, SMT3H1, CDK4, RPS4X, NRD1

Cell proliferation

DARS, RPL29, NACA, EIF3S6IP, RPL39, RPL23A, MRPL45,

Protein biosynthesis

MRPL43, RPL30, MRP63, MRPS27

B, Specific sets of genes down-regulated in Group 1 and up-regulated in Group 2

Gene symbol

Function

IGHM, TNFRSF4, THY1, LILRB4, EDG6, HCST, LY86, LIMR, CXCL14

Inflammation and immune response

FLT3LG, DOK4, GALR3, GRIN1, SLA, GNA12, ABR, TRPV5, CBRC7TM_2, Signal transduction

LOC90139, DRD1A, CBRC7TM_519, NTNG2, GPR14, GPR7, RAB6B

COL3A1, CSPG2, ARHGAP9, NRXN2, DPT, BAIAP1

Cell adhesion

tumors (143 genes) are mainly involved in signal transduction, regulation of transcription, immune response and inflammation, protein modification, metabolism and cell adhesion. Our data indicate the presence of some functional categories of differentially expressed genes that are specific for each of the two cluster groups (Table IV).

We further checked the mutation status of the p53 gene in these tumor samples and performed more detailed analysis of the clinical charts of the six patients in order to find any parameters that could potentially explain their clustering. The p53 mutation analysis showed some differences between the groups, since two Group 1 tumors carried different p53 mutations, while two Group 2 tumors contained the wildtype p53 gene with the codon 72 polymorphism (Table V). Interestingly, patient VOA149 had a mutation at codon 85 of the p53 gene only in the post-CT tumor sample, while the primary tumor contained the wild-type p53 allele, indicating that this mutation might be acquired during/after CT treatment. Analysis of different clinical parameters, including CA125 values, initial and residual tumor size, genetic predisposition, etc., did not displayed any significant differences between the two tumor groups (data not shown). The only substantial distinction between the patients from the two groups was the intensity of CT regimens between the two surgical inter- 


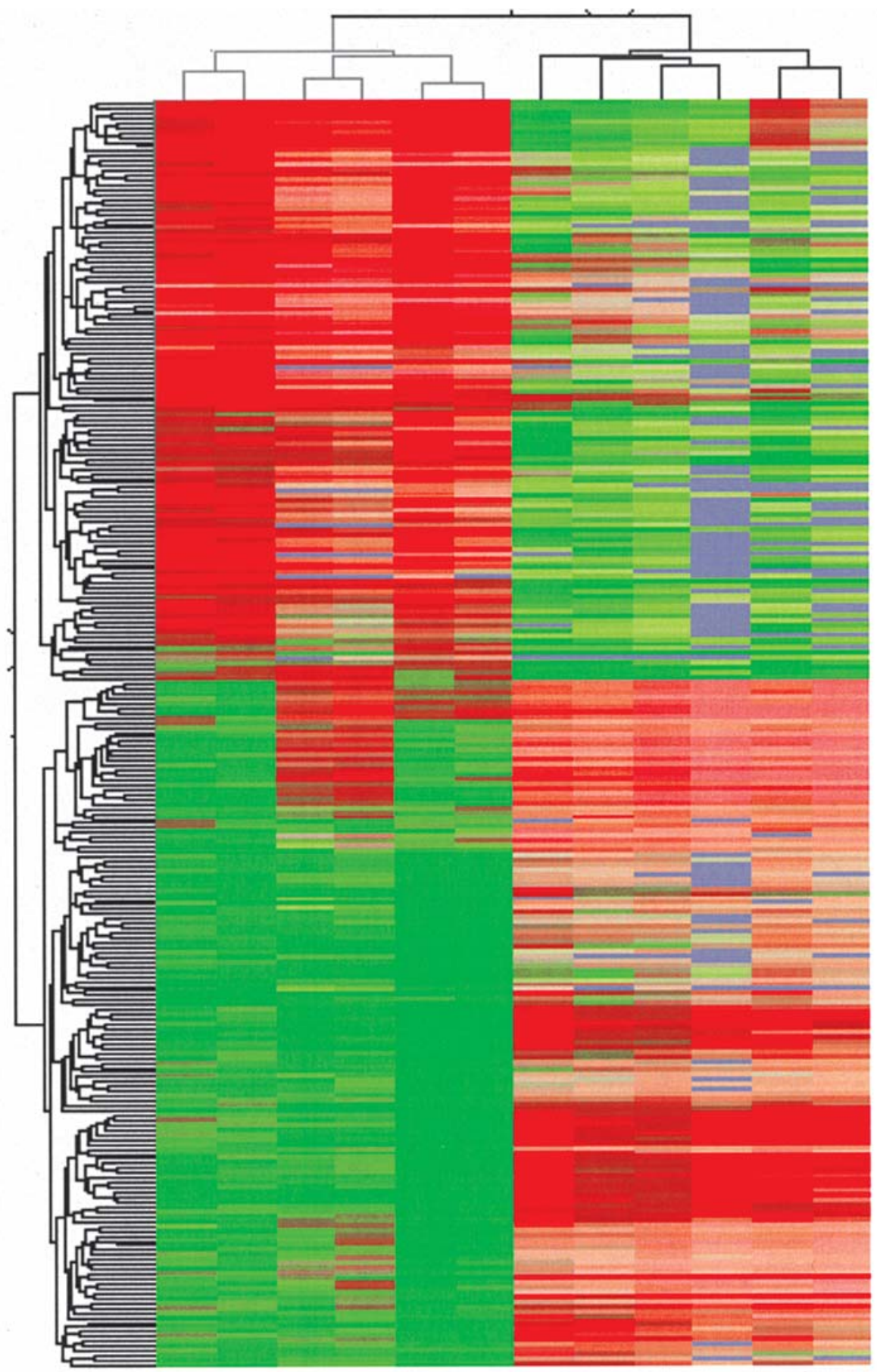

Group 1

Group 2

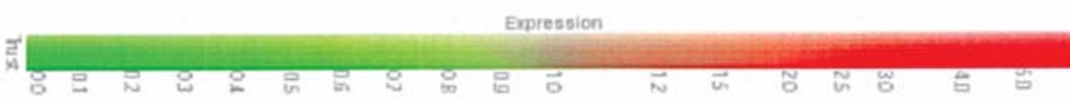

Figure 1. Hierarchical clustering of the 6 post-CT tumors in duplicate based on the 264 gene list (gene expression 2-fold; p-value cutoff of 0.005 ) that discriminates between Group 1 and Group 2 tumors. The mean appears grey, whereas red signifies up-regulation, and green signifies down-regulation (see legend bar). Group 1 tumors are indicated in grey; Group 2 tumors are indicated in blue.

ventions (the primary cytoreductive surgery and the secondlook laparotomy). During this period, the patients from Group 1 have received only one CT regimen, while the Group 2 patients have been more heavily treated, receiving at least two CT regimens (Table $\mathrm{V}$ ).

\section{Discussion}

In this study we have used the microarray technology to examine gene expression profiles of ovarian tumor samples obtained from the same patient prior to, and following systemic 
Table V. Individual CT treatment regimens and mutation status of the p53 gene in the tumor samples of the 6 ovarian cancer patients enrolled in the study.

\begin{tabular}{|c|c|c|c|c|}
\hline \multirow[b]{2}{*}{ Patient } & \multirow[b]{2}{*}{ Group } & \multicolumn{2}{|c|}{ p53 gene mutation status } & \multirow{2}{*}{$\begin{array}{l}\text { CT treatment between } \\
1 \text { st and } 2 \text { nd LAP }\end{array}$} \\
\hline & & Prior CT & Following CT & \\
\hline \multirow[t]{2}{*}{ VOA149 } & 1 & WT & Exon 4, codon $85(\mathrm{M})$ & TX-CP 9X \\
\hline & & & $\mathrm{CCT} \rightarrow \mathrm{CTT}(\mathrm{Pro} \rightarrow \mathrm{Val})$ & \\
\hline \multirow[t]{2}{*}{ OV-111 } & 1 & Exon 6, codon $218(\mathrm{M})$ & Exon 6, codon $218(\mathrm{M})$ & TX-CP 6X \\
\hline & & GTG $\rightarrow$ GAG $(\mathrm{Val} \rightarrow \mathrm{Glu})$ & GTG $\rightarrow$ GAG $($ Val $\rightarrow$ Glu $)$ & \\
\hline OV-234 & 1 & WT & WT & TX-CP 6X \\
\hline \multirow[t]{2}{*}{ OV-86 } & 2 & Exon 4, codon $72(\mathrm{P})$ & Exon 4 , codon $72(\mathrm{P})$ & TX-CP 6X; \\
\hline & & $\mathrm{CGC} \rightarrow \mathrm{CCC}(\mathrm{Arg} \rightarrow \mathrm{Pro})$ & $\mathrm{CGC} \rightarrow \mathrm{CCC}($ Arg $\rightarrow$ Pro $)$ & TX-6X \\
\hline \multirow[t]{2}{*}{$\mathrm{OV}-113$} & 2 & WT & WT & TX-CP 6X; \\
\hline & & & & TX-CP 6X; DOX 3X \\
\hline \multirow[t]{2}{*}{ OV-118 } & 2 & Exon 4, codon $72(\mathrm{P})$ & Exon 4, codon $72(\mathrm{P})$ & TX-CP 6X; \\
\hline & & $\mathrm{CGC} \rightarrow \mathrm{CCC}(\mathrm{Arg} \rightarrow \mathrm{Pro})$ & $\mathrm{CGC} \rightarrow \mathrm{CCC}(\mathrm{Arg} \rightarrow \mathrm{Pro})$ & TPT $4 \mathrm{X}$ \\
\hline
\end{tabular}

CT, adjuvant chemotherapy; LAP, laparotomy; TX, taxol; CP, carboplatin; TPT, topotecan; DOX, liposomal doxorubicin; WT, wild-type (non-mutated); (M), mutation; (P), polymorphism.

CT. Such samples are quite uncommon since second-look laparotomy is a very rare practice in treatment of ovarian carcinomas, and obviously these cases refer to aggressive/ metastatic cancer. Indeed, screening of our ovarian tumor bank which currently comprises more than 600 ovarian tumor specimens allowed us to find paired tumor samples (pre- and post-CT) only from 5 patients, as we have obtained paired samples from one more patient from the ovarian tumor collection in the University of British Columbia. For each patient, we performed pairwise gene expression comparison between pre- and post-CT tumor samples in order to gain insight into global changes describing the chemoresistant phenotype. To our knowledge, similar expression analyses using paired ovarian tumor samples with common origin (obtained from the same patient) have not been yet performed. The rationale for this approach was 2 -fold. First, we were able to compare gene expression profiles between primary and post-CT tumor samples with identical genetic background, thus avoiding any 'noise' due to individual's genetic variations. Second, after each cycle of cytotoxic CT, the 'log kill' effect leads to a significant reduction in the number of tumor cells that are sensitive to the administered therapy $(17,18)$. Hence, tumor samples obtained following CT are mostly derived from intrinsic resistant clones and are likely to display molecular signatures associated with chemoresistance. However, we cannot exclude the possibility that some tumor cells that survive the treatment are likely to experience changes in gene expression that allow them to withstand the selective pressure of the drugs used (acquired chemoresistance).

Using our selection criteria (expression 2-fold at $\mathrm{p}=0.05$ ), we observed that more than twice (121 of 175) genes had higher expression in the post-CT compared with the primary tumors. A similar imbalanced distribution has been observed for other CT-based gene sets, i.e., platinum resistance in 60 NCI cell lines (19), in 7 gastric cell lines (20), in taxol-resistant breast cancer specimens (21), and also quite recently, in resistant compared with sensitive ovarian tumors (22). Thus our data confirm previous findings that overexpression of discriminatory genes is more often associated with CT resistance than sensitivity (22).

As expected, post-CT tumors displayed up-regulation of several genes with functional relevance to mechanisms of chemoresistance (Table IIA). Notably, increased COX2 expression has been repeatedly associated with CT resistance in ovarian cancer patients $(23,24)$. Another member from the same gene family, COX7B, was also found to be up-regulated in post-CT breast tumors as compared to primary breast tumors (25). TOP2A gene overexpression has been formerly linked with mechanisms of chemoresistance (26-29), including ovarian cancer chemoresistance $(22,30,31)$. ETV4 (E1AF or PEA3) is a member of the Ets-related transcription factor family and has been associated with high rates of cell invasion in ovarian cancer $(32,33)$. Platinum treatment has been reported to up-regulate ETV4 (34) and ETV4 gene expression was significantly increased in cisplatin-resistant ovarian carcinoma (35). The ABCF2 protein is a member of the ABCF transporter superfamily and was found to be amplified in a chemoresistant ovarian cancer cells (36). Moreover, Tsuda et al recently reported that $\mathrm{ABCF} 2$ expression significantly correlated with gene amplification and $\mathrm{CT}$ response in clear cell ovarian adenocarcinomas, possibly contributing to the chemoresistant phenotype of this ovarian cancer histotype (37). PRDX2 has been known to be induced by various oxidative stimuli and to play an important protective role from oxidative damage (38). Its expression was correlated with resistance to apoptosis induced by ionizing radiation or cisplatin (39-41), highlighting 
the potential clinical importance of PRDX2 in chemoand radiation-resistance in cancer. We have also observed some increase in MUC1, MT3 and MT2A gene expression (Table IIA), which possibly contributes to the chemoresistant phenotype of the post-CT ovarian tumors. In parallel, some genes involved in chemosensitivity (GRP, TRA1, ADPRTL1, TRF4-2) were found to be down-regulated in the post-CT tumor specimens (Table IIB).

Additionally, numerous genes that have been implicated previously in tumorigenesis and more specifically in ovarian tumorigenesis were found to be up-regulated in post-CT tumors (Table IIA). For instance, S100A9 was found to be overexpressed in common cancers, including ovarian cancer (42). SFN gene expression and methylation status can characterize histological features of different types of ovarian cancer (43). ASS is an enzyme involved in the arginine biosynthesis as L-arginine represents the sole precursor for nitric oxide (NO) synthesis (44). NO enhances tumor initiation, promotion and progression, and it was suggested that argininedegrading enzyme therapy might be beneficial for cancer patients, including ovarian cancer patients (22). TACC3 has been recently identified as a novel biomarker of ovarian cancer (45). SRA1 displayed significant up-regulation in serous ovarian tumors compared with other ovarian tumor types and normal ovary (46). Recent reports revealed that COX1 contributes to carcinoma development in the ovary through stimulation of prostanglandin E2 production and neovascularization $(47,48)$ and thus represents a potential target for prevention and treatment of epithelial ovarian cancer (49).

All genes mentioned above provide targets for prospective investigations of intrinsic and/or acquired chemoresistance in ovarian cancer. Differences in RNA expression were confirmed by sqRT-PCR for a sample of genes.

Interestingly in post-CT tumor samples, the expression of some genes representing positive regulators of cell proliferation (NGFRAP1, TPD52L1, TAX1BP1) was suppressed, while several genes involved in negative regulation of cell proliferation (PPP2R4, H1F0, PBP, TP53I11) were found to be up-regulated (Table II). This observation supports the concept that decreased proliferation state of tumor cells may be involved in the development of acquired chemoresistance (50-54).

Unexpectedly, assessment of the individual post-CT/ pre-CT gene expression profiles of the six patients enrolled in this study revealed the existence of two distinct expression signatures of chemoresistant tumors, which was further confirmed by cluster analysis. Using highly stringent selection criteria (2-fold differential gene expression; $p$-value cutoff of $0.005)$ we have identified a set of 264 discriminatory genes for which expression differed between the 2 groups (Fig. 1). Thus, 121 genes from the 264-genes list were respectively upregulated in Group 1 tumors and down-regulated in Group 2 tumors, while 143 genes were found to be down-regulated in Group 1 tumors and correspondingly up-regulated in Group 2 tumors (Supplemental data Table I). Some functional categories of differentially expressed genes displayed group specificity. For instance, genes with functional relevance to mechanisms of cell proliferation and protein biosynthesis were mostly upregulated in Group 1 tumors, while genes involved in inflammation and immune response, signal transduction and cell adhesion, were predominantly up-regulated in Group 2 tumors (Table IV). Based on these data we could assume the existence of two subtypes of post-CT ovarian tumors with Group 2 tumors possibly displaying more chemoresistant/ aggressive phenotype than Group 1 tumors. Indeed, lower proliferation state, diminished protein biosynthesis and higher inflammation rates have been previously linked with chemoresitance (see above) and enhanced tumor progression $(55,56)$. The more aggressive and chemoresistant phenotype of Group 2 tumors could be additionally sustained by higher expression of genes involved in signal transduction and cell adhesion, since it was shown that cell adhesion molecules not only define a tumor cell's adhesive repertoire, but also directly influence classic signal transduction pathways, thereby modulating the metastatic behavior of tumor cells (57).

The above observation for the existence of 2 subtypes of chemoresistant ovarian tumors with Group 2 tumors displaying the more chemoresistant/aggressive phenotype was further supported by analyses of some additional parameters, including the p53 gene mutation status and CT treatment regimens (Table V). Thus, two of the Group 1 tumors carried different p53 missense mutations; however, p53 activity appears to have insignificant effect on response and survival to platinum-based treatment of ovarian tumors (58). In contrast, the p53 codon 72 polymorphism was found in two Group 2 tumors, and this polymorphism was previously linked with chemoresistance (59) and poor prognosis in ovarian cancer (60). Moreover, for the period between the two surgical interventions, Group 1 patients received only one CT regimen, while the Group 2 patients were more heavily treated, receiving at least two CT regimens which supports the suggestion for the more resistant phenotype of Group 2 tumors.

In summary, gene expression profiling has evidenced for specific expression signatures of chemoresistant post-CT ovarian tumors when compared with their paired primary tumors obtained from the same ovarian cancer patient. Our data suggest that intrinsic and acquired chemoresistant phenotypes of post-CT tumors may be attributed to the combined action of different factors implicated in mechanisms of chemoresistance, tumor invasion/progression and control of cell proliferation. Additionally, gene clustering analysis revealed the existence of two distinct expression signatures of chemoresistant tumors, which was further confirmed by assessment of some genetic and clinical parameters. It will be enlightening to carry out an extended study with more paired ovarian tumor samples in order to better understand the molecular mechanisms of ovarian cancer chemoresistance and the possible existence of different subtypes of chemoresistant tumors. This type of molecular profiling could have important clinical implications in resolving chemoresistance and the development of novel treatment strategies designed to prevent its emergence.

\section{Acknowledgements}

This study was supported by grant from the Cancer Research Society (CRS) of Canada (The Strategic Research Program on Genomics and Proteomics of Metastasic Cancer) and by financial support of the Cancer Research Network of the 'Fonds de la Recherche en Santé du Québec', Québec, Canada. 
We are thankful to Dr Blake Gilks (Department of Pathology and Laboratory Medicine, Vancouver General Hospital) for sending us paired pre-/post-CT tumor samples and corresponding clinical data from one ovarian cancer patient.

\section{References}

1. Ozols RF: Current status of chemotherapy for ovarian cancer. Semin Oncol 22: 61-66, 1995

2. McGuire WP and Ozols RF: Chemotherapy of advanced ovarian cancer. Semin Oncol 25: 340-348, 1998.

3. Markman M: Current status and future directions of platinum/ paclitaxel based chemotherapy of ovarian cancer. Semin Oncol 24: S1124-S1127, 1997.

4. Markmon M: Second-line chemotherapy of epithelial ovarian cancer. Expert Rev Anticancer Ther 3: 31-36, 2003.

5. Moss C and Kaye SB: Ovarian cancer: progress and continuing controversies in management. Eur J Cancer 38: 1701-1707, 2002.

6. Johnson SW, Ozols RF and Hamilton TC: Mechanisms of drug resistance in ovarian cancer. Cancer 71: 644-649, 1993.

7. Aebi S, Kurdihaidar B, Gordon R, et al: Loss of DNA mismatch repair in acquired resistance to cisplatin. Cancer Res 56: 3087-3090, 1996.

8. Coukos G and Rubin SC: Chemotherapy resistance in ovarian cancer: new molecular perspectives. Obstet Gynecol 91: 783-792, 1998.

9. Vasey PA: Resistance to chemotherapy in advanced ovarian cancer: mechanisms and current strategies. Br J Cancer 89: S23-S28, 2003.

10. Agarwal R and Kaye SB: Ovarian cancer: strategies for overcoming resistance to chemotherapy. Nat Rev Cancer 3: 502-516, 2003.

11. Germain I, Têtu B, Brisson J, Mondor M and Cherian G: Markers of chemoresistance in ovarian carcinomas; an immunohistochemical study of 86 cases. Int J Gynecol Pathol 15: 54-62, 1996.

12. Eltabbakh GH and Awtrey CS: Current treatment for ovarian cancer. Expert Opin Pharmacother 2: 109-124, 2001.

13. Goff BA, Paley PJ, Greer BE and Gown AM: Evaluation of chemoresistance markers in women with epithelial ovarian carcinoma. Gynecol Oncol 81: 18-24, 2001.

14. Angers M, Drouin R, Bachvarova M, Paradis I, Hiromura M, Usheva A and Bachvarov D: In vivo DNase I-mediated footprinting analysis along the human bradykinin B1 receptor (BDKRB1) gene promoter: evidence for cell-specific regulation. Biochem J 389: 37-46, 2005.

15. Markman M, Bundy BN, Alberts DS, Fowler JM, ClarkPearson DL, Carson LF, Wadler S and Sickel J: Phase III trial of standard-dose intravenous cisplatin plus paclitaxel versus moderately high-dose carboplatin followed by intravenous paclitaxel and intraperitoneal cisplatin in small-volume stage III ovarian carcinoma: an intergroup study of the Gynecologic Oncology Group, Southwestern Oncology Group, and Eastern Cooperative Oncology Group. J Clin Oncol 19: 1001-1007, 2001.

16. Ozols RF, Bundy BN, Greer BE, Fowler JM, Clarke-Pearson D, Burger RA, Mannel RS, DeGeest K, Hartenbach EM and Baergen R: Phase III trial of carboplatin and paclitaxel compared with cisplatin and paclitaxel in patients with optimally resected stage III ovarian cancer: a Gynecologic Oncology Group study. J Clin Oncol 21: 3194-3200, 2003.

17. Skipper HE: Kinetics of mammary tumor cell growth and implications for therapy. Cancer 28: 1479-1499, 1971.

18. Norton L, Simon R, Brereton HD and Bogden AE: Predicting the course of Gompertzian growth. Nature 264: 542-545, 1976.

19. Vekris A, Meynard D, Haaz MC, Bayssas M, Bonnet J and Robert J: Molecular determinants of the cytotoxicity of platinum compounds: the contribution of in silico research. Cancer Res 64: 356-362, 2004.

20. Kang HC, Kim IJ, Park JH, Shin Y, Ku JL, Jung MS, Yoo BC, Kim HK and Park JG: Identification of genes with differential expression in acquired drug-resistant gastric cancer cells using high-density oligonucleotide microarrays. Clin Cancer Res 10: 272-284, 2004

21. Chang JC, Wooten EC, Tsimelzon A, Hilsenbeck SG, Gutierrez MC, Elledge R, Mohsin S, Osborne CK, Chamness GC, Allred DC and O'Connell P: Gene expression profiling for the prediction of therapeutic response to docetaxel in patients with breast cancer. Lancet 362: 362-369, 2003.
22. Helleman J, Jansen MP, Span PN, van Staveren IL, Massuger LF, Meijer-van Gelder ME, Sweep FC, Ewing PC, van der Burg ME, Stoter G, Nooter K and Berns EM: Molecular profiling of platinum resistant ovarian cancer. Int J Cancer 118: 1963-1971, 2006.

23. Raspollini MR, Amunni G, Villanucci A, Boddi V and Taddei GL: Increased cyclooxygenase-2 (COX-2) and P-glycoprotein-170 (MDR1) expression is associated with chemotherapy resistance and poor prognosis. Analysis in ovarian carcinoma patients with low and high survival. Int J Gynecol Cancer 15: 255-260, 2005.

24. Ferrandina G, Lauriola L, Zannoni GF, Fagotti A, Fanfani F, Legge F, Maggiano N, Gessi M, Mancuso S, Ranelletti FO and Scambia G: Increased cyclooxygenase-2 (COX-2) expression is associated with chemotherapy resistance and outcome in ovarian cancer patients. Ann Oncol 13: 1205-1211, 2002.

25. Hannemann J, Oosterkamp HM, Bosch CA, Velds A, Wessels LF, Loo C, Rutgers EJ, Rodenhuis S and van de Vijver MJ: Changes in gene expression associated with response to neoadjuvant chemotherapy in breast cancer. J Clin Oncol 23: 3331-3342, 2005.

26. Eder JP Jr, Chan VT, Ng SW, Rizvi NA, Zacharoulis S, Teicher BA and Schnipper LE: DNA topoisomerase II expression is associated with alkylating agent resistance. Cancer Res 55: 6109-6116, 1995.

27. De Jong S, Timmer-Bosscha H, De Vries EG and Mulder NH: Effect of novobiocin on cisplatin cytotoxicity and DNA interstrand cross-link formation in a cisplatin-resistant, small-cell lung carcinoma cell line. Int J Cancer 53: 110-117, 1993.

28. Hashimoto S, Jing Y, Kawazoe N, Masuda Y, Nakajo S, Yoshida T, Kuroiwa Y and Nakaya K: Bufalin reduces the level of topoisomerase II in human leukemia cells and affects the cytotoxicity of anticancer drugs. Leuk Res 21: 875-883, 1997.

29. Barret JM, Calsou P, Larsen AK and Salles B: A cisplatinresistant murine leukemia cell line exhibits increased topoisomerase II activity. Mol Pharmacol 46: 431-436, 1994.

30. Hengstler JG, Lange J, Kett A, Dornhofer N, Meinert R, Arand M, Knapstein PG, Becker R, Oesch F and Tanner B: Contribution of c-erbB-2 and topoisomerase IIalpha to chemoresistance in ovarian cancer. Cancer Res 59: 3206-3214, 1999.

31. Van der Burg ME, De Wit R, van Putten WL, Logmans A, Kruit WH, Stoter G and Verweij J: Weekly cisplatin and daily oral etoposide is highly effective in platinum pretreated ovarian cancer. Br J Cancer 86: 19-25, 2002.

32. Nishikawa A, Iwasaki M, Akutagawa N, et al: Expression of various matrix proteases and Ets family transcriptional factors in ovarian cancer cell lines: correlation to invasive potential. Gynecol Oncol 79: 256-263, 2000.

33. Kaya M, Yoshida K, Higashino F, Mitaka T, Ishii S and Fujinaga K: A single ets-related transcription factor, E1 AF, confers invasive phenotype on human cancer cells. Oncogene 12: 221-227, 1996.

34. Funaoka K, Shindoh M, Yoshida K, et al: Activation of the p21(Waf1/Cip1) promoter by the ets oncogene family transcription factor E1AF. Biochem Biophys Res Commun 236: 79-82, 1997.

35. Macleod K, Mullen P, Sewell J, Rabiasz G, Lawrie S, Miller E, Smyth JF and Langdon SP: Altered ErbB receptor signaling and gene expression in cisplatin-resistant ovarian cancer. Cancer Res 65: 6789-6800, 2005

36. Yasui K, Mihara S, Zhao C, Okamoto H, Saito-Ohara F, Tomida A, Funato T, Yokomizo A, Naito S, Imoto I, Tsuruo T and Inazawa $\mathrm{J}$ : Alteration in copy numbers of genes as a mechanism for acquired drug resistance. Cancer Res 64: 1403-1410, 2004.

37. Tsuda H, Ito YM, Ohashi Y, Wong KK, Hashiguchi Y, Welch WR, Berkowitz RS, Birrer MJ and Mok SC: Identification of overexpression and amplification of ABCF2 in clear cell ovarian adenocarcinomas by cDNA microarray analyses. Clin Cancer Res 11: 6880-6888, 2005.

38. Netto LE, Kowaltowski AJ, Castilho RF and Vercesi AE: Thiol enzymes protecting mitochondria against oxidative damage. Methods Enzymol 348: 260-270, 2002.

39. Park SH, Chung YM, Lee YS, et al: Antisense of human peroxiredoxin II enhances radiation-induced cell death. Clin Cancer Res 6: 4915-4920, 2000.

40. Wang T, Tamae D, Le Bon T, Shively JE, Yen Y and Li JJ: The role of peroxiredoxin II in radiation-resistant MCF-7 breast cancer cells. Cancer Res 65: 10338-10346, 2005. 
41. Chung YM, Yoo YD, Park JK, Kim YT and Kim HJ: Increased expression of peroxiredoxin II confers resistance to cisplatin. Anticancer Res 21: 1129-1133, 2001.

42. Cross SS, Hamdy FC, Deloulme JC and Rehman I: Expression of S100 proteins in normal human tissues and common cancers using tissue microarrays: S100A6, S100A8, S100A9 and S100A11 are all overexpressed in common cancers. Histopathology 46 : 256-269, 2005.

43. Kaneuchi M, Sasaki M, Tanaka Y, Shiina H, Verma M, Ebina Y, Nomura E, Yamamoto R, Sakuragi N and Dahiya R: Expression and methylation status of 14-3-3 sigma gene can characterize the different histological features of ovarian cancer. Biochem Biophys Res Commun 316: 1156-1162, 2004.

44. Lind DS: Arginine and cancer. J Nutr 134: 2837S-2841S, 2004.

45. Peters DG, Kudla DM, Deloia JA, Chu TJ, Fairfull L, Edwards RP and Ferrell RE: Comparative gene expression analysis of ovarian carcinoma and normal ovarian epithelium by serial analysis of gene expression. Cancer Epidemiol Biomarkers Prev 14: 1717-1723, 2005.

46. Hussein-Fikret S and Fuller PJ: Expression of nuclear receptor coregulators in ovarian stromal and epithelial tumours. Mol Cell Endocrinol 14: 149-160, 2005.

47. Kino Y, Kojima F, Kiguchi K, Igarashi R, Ishizuka B and Kawai S: Prostaglandin E2 production in ovarian cancer cell lines is regulated by cyclooxygenase- 1 , not cyclooxygenase- 2 . Prostaglandins Leukot Essent Fatty Acids 73: 103-111, 2005.

48. Gupta RA, Tejada LV, Tong BJ, Das SK, Morrow JD, Dey SK and Du Bois RN: Cyclooxygenase- 1 is overexpressed and promotes angiogenic growth factor production in ovarian cancer. Cancer Res 63: 906-911, 2003.

49. Daikoku T, Wang D, Tranguch S, Morrow JD, Orsulic S, Du Bois RN and Dey SK: Cyclooxygenase-1 is a potential target for prevention and treatment of ovarian epithelial cancer. Cancer Res 65: 3735-3744, 2005.

50. Itamochi H, Kigawa J, Sugiyama T, Kikuchi Y, Suzuki M and Terakawa N: Low proliferation activity may be associated with chemoresistance in clear cell carcinoma of the ovary. Obstet Gynecol 100: 281-287, 2002.
51. Muller V, Stahmann N, Riethdorf S, Rau T, Zabel T, Goetz A, Janicke $\mathrm{F}$ and Pantel K: Circulating tumor cells in breast cancer: correlation to bone marrow micrometastases, heterogeneous response to systemic therapy and low proliferative activity. Clin Cancer Res 11: 3678-3685, 2005.

52. Linn SC, Pinedo HM, van Ark-Otte J, van der Valk P, Hoekman K, Honkoop AH, Vermorken JB and Giaccone G: Expression of drug resistance proteins in breast cancer, in relation to chemotherapy. Int J Cancer 71: 787-795, 1997.

53. Yang KP, Liang YF and Samaan NA: Intrinsic drug resistance in a human medullary thyroid carcinoma cell line: association with overexpression of mdrl gene and low proliferation fraction. Anticancer Res 11: 1065-1068, 1991.

54. Jazaeri AA, Awtrey CS, Chandramouli GV, Chuang YE, Khan J, Sotiriou C, Aprelikova O, Yee CJ, Zorn KK, Birrer MJ, Barrett JC and Boyd J: Gene expression profiles associated with response to chemotherapy in epithelial ovarian cancers clinical cancer. Clin Cancer Res 11: 6300-6310, 2005.

55. Holland EC, Sonenberg N, Pandolfi PP and Thomas G: Signaling control of mRNA translation in cancer pathogenesis. Oncogene 23: 3138-3144, 2004.

56. Coussens LM and Werb Z: Inflammation and cancer. Nature 420: 860-867, 2002.

57. Cavallaro U and Christofori G: Multitasking in tumor progression: signaling functions of cell adhesion molecules. Ann NY Acad Sci 1014: 58-66, 2004.

58. Clarke PA, Pestell KE, Di Stefano F, Workman P and Walton MI: Characterization of molecular events following cisplatin treatment of two curable ovarian cancer models: contrasting role for p53 induction and apoptosis in vivo. Br J Cancer 91: 1614-1623, 2004.

59. Sullivan A, Syed N, Gasco M, Bergamaschi D, Trigiante G, Attard M, Hiller L, Farrell PJ, Smith P, Lu X and Crook T: Polymorphism in wild-type p53 modulates response to chemotherapy in vitro and in vivo. Oncogene 23: 3328-3337, 2004.

60. Hogdall EV, Hogdall CK, Christensen L, Glud E, Blaakaer J, Bock JE, Vuust J, Norgaard-Pedersen B and Kjaer SK: Distribution of p53 codon 72 polymorphisms in ovarian tumour patients and their prognostic significance in ovarian cancer patients. Anticancer Res 22: 1859-1864, 2002.

Supplementary Table I. List of differentially expressed genes (2-fold; $\mathrm{p}=0.05)$ in post-CT ovarian tumors compared to pre-CT tumors.

\begin{tabular}{|c|c|c|c|}
\hline Normalized data & Common & GenBank & Description \\
\hline 4.67 & SCGB2A2 & $\mathrm{U} 33147$ & Secretoglobin, family $2 \mathrm{~A}$, member 2 \\
\hline 3.74 & S100A9 & AF086362 & S100 calcium binding protein A9 (calgranulin B) \\
\hline 3.53 & TRAP95 & AF121228 & Thyroid hormone receptor-associated protein, $95-\mathrm{kDa}$ subunit \\
\hline 3.34 & TTK & BC032858 & TTK protein kinase \\
\hline 3.06 & RERE & NM_012102 & Arginine-glutamic acid dipeptide (RE) repeats \\
\hline 3.03 & KRT6A & ВC014152 & Keratin $6 \mathrm{~A}$ \\
\hline 2.99 & MELK & D79997 & Maternal embryonic leucine zipper kinase \\
\hline 2.95 & NPL4 & AK000664 & Hypothetical protein FLJ20657 \\
\hline 2.93 & MRPL12 & NM_002949 & Mitochondrial ribosomal protein L12 \\
\hline 2.89 & YWHAE & ВС001440 & Tyrosine 3-monooxygenase/tryptophan 5-monooxygenase activation protein, epsilon \\
\hline 2.89 & ETV4 & NM_001986 & Ets variant gene 4 (E1A enhancer binding protein, E1AF) \\
\hline 2.86 & FKBP8 & NM_012181 & FK506 binding protein $8,38 \mathrm{kDa}$ \\
\hline 2.83 & PRSS2 & ВC030260 & Protease, serine, 2 (trypsin 2) \\
\hline 2.80 & UGCG & D50840 & UDP-glucose ceramide glucosyltransferase \\
\hline 2.80 & & AF023860 & Cercopithecus aethiops cyclophilin A \\
\hline 2.76 & & AF023861 & Macaca mulatta cyclophilin A mRNA \\
\hline 2.76 & SFN & AF029081 & 14-3-3 sigma protein promoter and gene \\
\hline 2.75 & P4HB & ВC029617 & Procollagen-proline, 2-oxoglutarate 4-dioxygenase (proline 4-hydroxylase), beta \\
\hline 2.72 & KRT6E & NM_173086 & Keratin $6 \mathrm{E}$ \\
\hline 2.67 & EPN3 & NM_017957 & Epsin 3 \\
\hline 2.67 & & AF023860 & Cercopithecus aethiops cyclophilin A \\
\hline 2.65 & HSPB1 & Z23090 & $28 \mathrm{kDa}$ heat shock protein \\
\hline
\end{tabular}


Supplementary Table I. Continued.

\begin{tabular}{|c|c|c|c|}
\hline Normalized data & Common & GenBank & Description \\
\hline 2.62 & PPP2R4 & BC002545 & Protein phosphatase 2A, regulatory subunit B' (PR 53) \\
\hline 2.61 & ATP6AP1 & ВC000724 & ATPase, $\mathrm{H}+$ transporting, lysosomal accessory protein 1 \\
\hline 2.58 & PP3111 & NM_022156 & PP3111 protein \\
\hline 2.58 & DCXR & AF113123 & Dicarbonyl/L-xylulose reductase \\
\hline 2.56 & UQCRC1 & L16842 & Ubiquinol-cytochrome $\mathrm{c}$ reductase core protein I \\
\hline 2.54 & MGC5528 & NM_024094 & Defective in sister chromatid cohesion homolog 1 (S. cerevisiae) \\
\hline 2.54 & CLTB; LCB & M20469 & Clathrin light-chain b; human brain-type clathrin light-chain b mRNA, complete cds \\
\hline 2.54 & MGC2198 & NM_138820 & Hypothetical protein MGC2198 \\
\hline 2.52 & $\mathrm{ABCF} 2$ & NM_005692 & ATP-binding cassette, sub-family F (GCN20), member 2 \\
\hline 2.50 & COPE & AL136928 & Coatomer protein complex, subunit epsilon \\
\hline 2.49 & ZNF141 & NM_003441 & Zinc finger protein 141 (clone pHZ-44) \\
\hline 2.48 & USP5 & U47927 & Ubiquitin specific protease 5 (isopeptidase T) \\
\hline 2.46 & CAPNS2 & BC005397 & Calpain small subunit 2 \\
\hline 2.45 & & & Protein containing three $\mathrm{C} 2 \mathrm{H} 2$ type zinc finger domains \\
\hline 2.45 & DAPK3 & АB007144 & Death-associated protein kinase 3 \\
\hline 2.45 & PRDX2 & ВC039428 & Peroxiredoxin 2 \\
\hline 2.44 & FBXW5 & NM_018998 & F-box and WD-40 domain protein 5 \\
\hline 2.44 & TP53TG3 & NM_015369 & TP53TG3 protein \\
\hline 2.42 & CBARA1 & NM_006077 & Calcium binding atopy-related autoantigen 1 \\
\hline 2.39 & ASS & X01630 & Agininosuccinate synthetase \\
\hline 2.39 & FLJ21125 & NM_024627 & Hypothetical protein FLJ21125 \\
\hline 2.39 & H1F0 & ВC000145 & H1 histone family, member 0 \\
\hline 2.39 & NCOA3 & NM_006534 & Nuclear receptor coactivator 3 \\
\hline 2.38 & EIF2AK3 & AF110146 & Eukaryotic translation initiation factor 2-alpha kinase 3 \\
\hline 2.37 & LOC283820 & BC041131 & Hypothetical protein LOC283820 \\
\hline 2.36 & PSMD3 & D67025 & Proteasome (prosome, macropain) 26S subunit, non-ATPase, 3 \\
\hline 2.36 & TACC3 & AF093543 & Transforming, acidic coiled-coil containing protein 3 \\
\hline 2.35 & FLII & NM_002018 & Flightless I homolog (Drosophila) \\
\hline 2.34 & IDH3G & U40272 & Isocitrate dehydrogenase $3(\mathrm{NAD}+)$ gamma \\
\hline 2.32 & SLC25A5 & NM_001152 & Solute carrier family 25 member 5 \\
\hline 2.31 & $\mathrm{COX} 2$ & NM_173705 & Cytochrome c oxidase II \\
\hline 2.30 & ARHGAP4 & X78817 & Rho GTPase activating protein 4 \\
\hline 2.28 & TRIM26 & ВC032297 & Tripartite motif-containing 26 \\
\hline 2.28 & CDC42EP1 & ВC009356 & CDC42 effector protein (Rho GTPase binding) 1 \\
\hline 2.28 & PDE9A & AF048837 & Phosphodiesterase 9A \\
\hline 2.27 & MGC20806 & NM_144999 & Hypothetical protein MGC20806 \\
\hline 2.27 & SRA1 & AF293024 & Steroid receptor RNA activator 1 \\
\hline 2.26 & LMAN2 & U10362 & Lectin, mannose-binding 2 \\
\hline 2.25 & HARS & AK000498 & Histidyl-tRNA synthetase \\
\hline 2.24 & CASKIN2 & NM_020753 & CASK interacting protein 2 \\
\hline 2.24 & DAP4 & AB023181 & Disks large-associated protein 4 \\
\hline 2.24 & MGC2641 & $\mathrm{BC} 000755$ & Hepatoma-derived growth factor-related protein 2 \\
\hline 2.23 & APTX & NM_175073 & Aprataxin \\
\hline 2.22 & PP1201 & AK090618 & PP1201 protein \\
\hline 2.22 & TNRC5 & ВC004423 & Trinucleotide repeat containing 5 \\
\hline 2.22 & ACY1 & L07548 & Aminoacylase 1 \\
\hline 2.22 & MGC35136 & NM_152427 & Hypothetical protein MGC35136 \\
\hline 2.21 & PSAP & D00422 & Prosaposin \\
\hline 2.21 & ZSIG11 & AK023997 & Putative secreted protein ZSIG11 \\
\hline 2.21 & RFWD1 & NM_032271 & Ring finger and WD repeat domain 1 \\
\hline 2.21 & FLJ20641 & NM_017915 & Hypothetical protein FLJ20641 \\
\hline
\end{tabular}


Supplementary Table I. Continued.

\begin{tabular}{|c|c|c|c|}
\hline Normalized data & Common & GenBank & Description \\
\hline 2.21 & SPTAN1 & NM_003127 & Spectrin, alpha, non-erythrocytic 1 (alpha-fodrin) \\
\hline 2.20 & RGS19IP1 & ВC012810 & Regulator of G-protein signalling 19 interacting protein 1 \\
\hline 2.20 & SORT1 & NM_002959 & Sortilin 1 \\
\hline 2.20 & GMPPA & NM_013335 & GDP-mannose pyrophosphorylase A \\
\hline 2.20 & CDA017 & NM_032024 & CDA017 protein \\
\hline 2.20 & SIAT7E & AK056241 & Sialyltransferase 7E \\
\hline 2.19 & HSU79266 & NM_013299 & Protein predicted by clone 23627 \\
\hline 2.18 & LGALS3BP & BC015761 & Lectin, galactoside-binding, soluble, 3 binding protein \\
\hline 2.18 & ARHGEF15 & ВC036749 & Rho guanine nucleotide exchange factor (GEF) 15 \\
\hline 2.17 & GPRC5C & NM_018653 & $\mathrm{G}$ protein-coupled receptor, family $\mathrm{C}$, group 5 , member $\mathrm{C}$ \\
\hline 2.16 & TCF15 & NM_004609 & Transcription factor 15 (basic helix-loop-helix) \\
\hline 2.16 & GDI1 & ВC012201 & GDP dissociation inhibitor 1 \\
\hline 2.15 & STMN4 & BC011520 & Stathmin-like 4 \\
\hline 2.15 & & X52858 & Human cyclophilin-related processed pseudogene \\
\hline 2.14 & & X52855 & Human cyclophilin-related processed pseudogene \\
\hline 2.14 & C20orf129 & NM_030919 & Chromosome 20 open reading frame 129 \\
\hline 2.14 & TUBA4 & NM_025019 & Tubulin, alpha 4 \\
\hline 2.12 & NICE-4 & D63478 & NICE-4 protein \\
\hline 2.12 & CRIP2 & ВC034151 & Cysteine-rich protein 2 \\
\hline 2.11 & PHB & S85655 & Prohibitin \\
\hline 2.11 & C19orf4 & ВC010446 & Chromosome 19 open reading frame 4 \\
\hline 2.11 & RHO & S76579 & Macaca fascicularis opsin mRNA \\
\hline 2.10 & DHX8 & D50487 & DEAH (Asp-Glu-Ala-His) box polypeptide 8 \\
\hline 2.10 & EST1B & NM_015327 & Est1p-like protein B \\
\hline 2.10 & IRF3 & Z56281 & Interferon regulatory factor 3 \\
\hline 2.09 & PSMD11 & AF001212 & Proteasome (prosome, macropain) 26S subunit, non-ATPase, 11 \\
\hline 2.08 & GCN5L1 & D64007 & GCN5 general control of amino-acid synthesis 5-like 1 (yeast) \\
\hline 2.07 & TMPRSS3 & NM_024022 & Transmembrane protease, serine 3 \\
\hline 2.07 & MT & ВC042195 & Malonyl-CoA:acyl carrier protein transacylase (malonyltransferase) \\
\hline 2.07 & LOC55974 & ВC005943 & Stromal cell protein \\
\hline 2.06 & AMY2B & NM_020978 & Amylase, alpha 2B; pancreatic \\
\hline 2.06 & PPIA & ВC013915 & Peptidylprolyl isomerase A (cyclophilin A) \\
\hline 2.06 & COX1 & NM_173704 & Cytochrome c oxidase I \\
\hline 2.05 & NLGN2 & AF376802 & Neuroligin 2 \\
\hline 2.05 & COX7B & Z14244 & Cytochrome c oxidase subunit VIIb \\
\hline 2.04 & FLJ20989 & NM_023080 & Hypothetical protein FLJ20989 \\
\hline 2.04 & PAFAH1B2 & ВС000398 & Platelet-activating factor acetylhydrolase, isoform $\mathrm{Ib}$, beta subunit $30 \mathrm{kDa}$ \\
\hline 2.02 & CD47 & X69398 & CD47 antigen (Rh-related antigen, integrin-associated signal transducer) \\
\hline 2.02 & PGLS & ВC014006 & 6-phosphogluconolactonase \\
\hline 2.02 & MGC13102 & NM_032323 & Hypothetical protein MGC13102 \\
\hline 2.02 & C14orf59 & NM_174976 & Chromosome 14 open reading frame 59 \\
\hline 2.02 & GRB2 & NM_002086 & Growth factor receptor-bound protein 2 \\
\hline 2.01 & HUMPPA & ВC047534 & Paraneoplastic antigen \\
\hline 2.01 & ET & AK000233 & Hypothetical protein ET \\
\hline 2.01 & $\mathrm{C} 40$ & NM_017546 & Hypothetical protein $\mathrm{C} 40$ \\
\hline 2.01 & RNF44 & NM_014901 & Ring finger protein 44 \\
\hline 2.01 & TP53I11 & NM_006034 & Tumor protein p53 inducible protein 11 \\
\hline 2.00 & TRAP100 & NM_014815 & Thyroid hormone receptor-associated protein (100 kDa) \\
\hline-2.00 & HT011 & NM_018472 & Uncharacterized hypothalamus protein HT011 \\
\hline-2.00 & GYPB & X08055 & Glycophorin B (includes Ss blood group) \\
\hline-2.01 & MORC & AF084946 & Microrchidia homolog (mouse) \\
\hline
\end{tabular}


Supplementary Table I. Continued.

\begin{tabular}{|c|c|c|c|}
\hline Normalized data & Common & GenBank & Description \\
\hline-2.02 & SAA4 & M81349 & Serum amyloid A4, constitutive \\
\hline-2.03 & ABCA6 & AY028898 & ATP-binding cassette, sub-family A (ABC1), member 6 \\
\hline-2.03 & ADAMTS5 & AF142099 & A disintegrin-like and metalloprotease with thrombospondin type 1 motif 5 \\
\hline-2.03 & FLJ14927 & NM_032863 & Protein of unknown function \\
\hline-2.04 & BTF3 & X53280 & Basic transcription factor 3 \\
\hline-2.04 & LOC139231 & AK091221 & Hypothetical protein $\mathrm{BC} 016683$ \\
\hline-2.05 & CSF1R & X03663 & Colony stimulating factor 1 receptor \\
\hline-2.06 & $\mathrm{C} 1 \mathrm{R}$ & ВC035220 & Complement component $1, \mathrm{r}$ subcomponent \\
\hline-2.06 & ANKRD15 & NM_015158 & Ankyrin repeat domain 15 \\
\hline-2.08 & FLJ10652 & NM_018169 & Hypothetical protein FLJ10652 \\
\hline-2.10 & KCTD12 & NM_138444 & Potassium channel tetramerisation domain containing 12 \\
\hline-2.11 & MAGP2 & U37283 & Microfibril-associated glycoprotein-2 \\
\hline-2.13 & SH3BGR & NM_007341 & SH3 domain binding glutamic acid-rich protein \\
\hline-2.13 & POGZ & AB007930 & Pogo transposable element with ZNF domain \\
\hline-2.14 & LMX1A & NM_177398 & LIM homeobox transcription factor 1, alpha \\
\hline-2.15 & ASXH2 & NM_018263 & Polycomb group protein ASXH2 \\
\hline-2.16 & TPD52L1 & U44427 & Tumor protein D52-like 1 \\
\hline-2.16 & SHBG & X05403 & Sex hormone-binding globulin \\
\hline-2.16 & KIR2DL1 & NM_014218 & Killer cell immunoglobulin-like receptor \\
\hline-2.16 & EEF1B2 & X60489 & Eukaryotic translation elongation factor 1 beta 2 \\
\hline-2.18 & RPS7 & ВC002866 & Ribosomal protein $\mathrm{S} 7$ \\
\hline-2.19 & & AK025719 & Homo sapiens cDNA: FLJ22066 fis, clone HEP10611 \\
\hline-2.19 & EPB42 & NM_000119 & Erythrocyte membrane protein band 4.2 \\
\hline-2.19 & DKFZp434G118 & NM_032266 & Hypothetical protein DKFZp434G118 \\
\hline-2.20 & MATN3 & $\mathrm{AJ} 224741$ & Matrilin 3 \\
\hline-2.25 & PLAT & ВC007231 & Plasminogen activator, tissue \\
\hline-2.26 & FLJ30213 & NM_145008 & Hypothetical protein FLJ30213 \\
\hline-2.26 & GUCY2D & M92432 & Guanylate cyclase 2D, membrane (retina-specific) \\
\hline-2.27 & FLJ10210 & NM_018027 & Hypothetical protein FLJ10210 \\
\hline-2.28 & LPA & NM_005577 & Lipoprotein, Lp(a) \\
\hline-2.28 & EAR3 & $\mathrm{X} 12795$ & v-erbA related ear-3 gene \\
\hline-2.29 & FMOD & ВC035281 & Fibromodulin \\
\hline-2.29 & NGFRAP1 & M38188 & Nerve growth factor receptor (TNFRSF16) associated protein 1 \\
\hline-2.33 & PAP & ВC036776 & Pancreatitis-associated protein \\
\hline-2.33 & $\mathrm{CDC} 26$ & NM_139286 & Cell division cycle 26 \\
\hline-2.36 & SERPING1 & ВC011171 & Serine (or cysteine) proteinase inhibitor, clade G member 1 \\
\hline-2.44 & F2RL1 & ВC018130 & Coagulation factor II (thrombin) receptor-like 1 \\
\hline-2.47 & GRP & ВC004488 & Gastrin-releasing peptide \\
\hline-2.54 & KYNU & U57721 & Kynureninase (L-kynurenine hydrolase) \\
\hline-2.58 & LOC57151 & & Member of the alpha-lactalbumin or lysozyme $\mathrm{C}$ family \\
\hline-2.62 & S100B & ВС001766 & S100 calcium binding protein, beta (neural) \\
\hline-2.63 & ARSF & NM_004042 & Arylsulfatase F \\
\hline-2.70 & FCGR1A & NM_000566 & Fc fragment of IgG, high affinity Ia, receptor for (CD64) \\
\hline-2.79 & FLJ13710 & NM_024817 & Hypothetical protein FLJ13710 \\
\hline-2.85 & DKFZp547H025 & NM_020161 & Hypothetical protein DKFZp547H025 \\
\hline-2.87 & SGCD & NM_000337 & Sarcoglycan, delta \\
\hline-3.18 & FERD3L & NM_152898 & Fer3-like (Drosophila) \\
\hline-3.55 & TIMP3 & S78453 & Tissue inhibitor of metalloproteinase 3 \\
\hline-4.00 & FHL2 & L42176 & Four and a half LIM domains 2 \\
\hline-4.65 & SMOC2 & AJ420521 & SPARC related modular calcium binding 2 \\
\hline-4.76 & OLFM3 & AF397394 & Olfactomedin 3 \\
\hline
\end{tabular}


Supplementary Table II. Genes selected upon cluster analysis from condition Group 1 that are greater or less than those in condition Group 2 by a factor of 2-fold at p-value cutoff $=0.005$.

\begin{tabular}{|c|c|c|c|c|}
\hline $\begin{array}{l}\text { Fold } \\
\text { change }\end{array}$ & Common & GenBank & Product & GO biological process \\
\hline 10.13 & FLJ10637 & ВС003081 & Hypothetical protein FLJ10637 & Unknown function \\
\hline 6.96 & BAT1 & ВC004350 & Unknown (protein for MGC:1518) & Unknown function \\
\hline 6.81 & FLJ12895 & NM_023926 & Hypothetical protein FLJ12895 & Unknown function \\
\hline 5.93 & BECN1 & NM_003766 & Beclin 1 & Anti-apoptosis \\
\hline 5.66 & LOC163233 & ВC015765 & & Unknown function \\
\hline 5.33 & C21orf59 & AK098577 & Chromosome 21 open reading frame 59 & Unknown function \\
\hline 5.06 & CDK4 & M14505 & $\begin{array}{l}\text { Cyclin-dependent kinase } 4 \text { isoform } 1 \\
\text { cyclin-dependent kinase } 4 \text { isoform } 2\end{array}$ & Cell proliferation \\
\hline 5.02 & TGIF & NM_173207 & $\begin{array}{l}\text { TG-interacting factor isoform c; TG-interacting factor isoform a; } \\
\text { TG-interacting factor isoform b; TG-interacting factor isoform d }\end{array}$ & Development \\
\hline 4.86 & TGIF & NM_170695 & $\begin{array}{l}\text { TG-interacting factor isoform c; TG-interacting factor isoform a; } \\
\text { TG-interacting factor isoform b; TG-interacting factor isoform d }\end{array}$ & Development \\
\hline 4.79 & TERF1 & U40705 & $\begin{array}{l}\text { Telomeric repeat binding factor } 1 \text { isoform } 2 \text {; } \\
\text { telomeric repeat binding factor } 1 \text { isoform } 1\end{array}$ & Cell proliferation \\
\hline 4.70 & HES 1 & NM_005524 & Hairy and enhancer of split 1 & Regulation of transcription \\
\hline 4.65 & SMT3H1 & ВC000036 & SMT3 suppressor of mif two 3 homolog 1 & Cell proliferation \\
\hline 4.50 & OAZIN & & & $\begin{array}{l}\text { Protein catabolism; } \\
\text { ubiquitin cycle }\end{array}$ \\
\hline 4.23 & KIAA0121 & D50911 & KIAA0121 protein & Unknown function \\
\hline 3.93 & MYST3 & NM_006766 & MYST histone acetyltransferase (monocytic leukemia) 3 & Chromosome organization \\
\hline 3.88 & MRPL43 & NM_032112 & Mitochondrial ribosomal protein L43 isoform a; & Protein biosynthesis \\
\hline
\end{tabular}

AB029309 WW domain binding protein 11

NM_003348 Ubiquitin-conjugating enzyme E2N

NM_025189 Zinc finger protein 430

BC004155 Ring finger protein 5

NM_052852

NM_024611 NMDA receptor-regulated gene 2

NM_014925

NM_175910 Zinc finger protein 493

M16660 Heat shock $90 \mathrm{kDa}$ protein 1, beta

NM_018246 Hypothetical protein FLJ10853

BC029265 Eukaryotic translation initiation factor 3, subunit 6 interacting protein

NM_174948 Hypothetical protein LOC285458

Retired

Signal transduction

Unknown function

Regulation of transcription

DNA repair

Regulation of transcription

Cell motility inhibitor

Unknown function

Development

Retired

\section{AK026528}

M58458

Ribosomal protein $\mathrm{S} 4$, X-linked X isoform

AK000069 FtsJ homolog 3

BC008926 Ribosomal protein L29

AK096205

BC014482

Signal transducer and activator of transcription 3 isoform 2; signal transducer and activator of transcription 3 isoform 1

Unknown function

Protein folding

Unknown function

Protein biosynthesis

Unknown function

Protein biosynthesis

Cell proliferation

Regulation of translation

Protein biosynthesis

Unknown function

Cell motility

Unknown function 
Supplementary Table II. Continued.

\begin{tabular}{|c|c|c|c|c|}
\hline $\begin{array}{l}\text { Fold } \\
\text { change }\end{array}$ & Common & GenBank & Product & GO biological process \\
\hline 3.22 & MGC32124 & ВC020263 & Hypothetical protein MGC32124 & Unknown function \\
\hline 3.18 & KIAA1737 & NM_033426 & KIAA1737 protein & Unknown function \\
\hline 3.14 & MGC32124 & NM_144611 & Hypothetical protein MGC32124 & Unknown function \\
\hline 3.10 & Raptor & NM_020761 & Raptor & Signal transduction \\
\hline 3.09 & ZNF43 & X59244 & Zinc finger protein 43 (HTF6) & Regulation of transcription \\
\hline 3.08 & C7orf30 & ВC012331 & Chromosome 7 open reading frame 30 & Unknown function \\
\hline 3.08 & GDI1 & ВC012201 & GDP dissociation inhibitor 1 & Protein transport \\
\hline 3.07 & MASA & AK022656 & E-1 enzyme & Metabolism \\
\hline 3.07 & ZNF430 & NM_025189 & Zinc finger protein 430 & Regulation of transcription \\
\hline 3.05 & H-plk & M55422 & Krueppel-related zinc finger protein & Unknown function \\
\hline 3.03 & ZNF85 & U35376 & Zinc finger protein 85 (HPF4, HTF1) & Regulation of transcription \\
\hline 3.01 & KIAA1924 & NM_145294 & Similar to RIKEN cDNA 3230401M21 (Mus musculus) & Unknown function \\
\hline 3.01 & SMARCA5 & ВС023144 & $\begin{array}{l}\text { SWI/SNF-related matrix-associated actin-dependent } \\
\text { regulator of chromatin a5 }\end{array}$ & Chromosome organization \\
\hline 3.00 & KIAA1279 & NM_015634 & KIAA1279 & Unknown function \\
\hline 2.99 & & & & Regulation of transcription \\
\hline 2.97 & PRNP & M13899 & Prion protein preproprotein & Immune response \\
\hline 2.96 & ZNF43 & X59244 & Zinc finger protein 43 (HTF6) & Regulation of transcription \\
\hline 2.95 & ZNF161 & NM_007146 & Zinc finger protein 161 & Defense response \\
\hline 2.88 & TIZ & NM_138330 & TRAF6-inhibitory zinc finger protein & Regulation of transcription \\
\hline 2.88 & MLL4 & NM_014727 & Myeloid/lymphoid or mixed-lineage leukemia 4 & Regulation of transcription \\
\hline 2.80 & TACC3 & AF093543 & Transforming, acidic coiled-coil containing protein 3 & Cell proliferation \\
\hline 2.80 & ТP53BP2 & U58334 & Tumor protein $\mathrm{p} 53$ binding protein 2 & Apoptosis \\
\hline 2.79 & RPL39 & ВС001019 & Ribosomal protein L39 & Protein biosynthesis \\
\hline 2.79 & C21orf 108 & $\mathrm{AB} 011111$ & KIAA0539 protein & Unknown function \\
\hline 2.77 & DPH2L1; OVCA1 & ВС003099 & $\begin{array}{l}\text { Diptheria toxin resistance protein required for diphthamide } \\
\text { biosynthesis-like } 1\end{array}$ & Tumor suppressor \\
\hline 2.74 & FKSG17 & NM_032031 & FKSG17 & Unknown function \\
\hline 2.71 & FBXL5 & NM_012161 & $\begin{array}{l}\text { F-box and leucine-rich repeat protein } 5 \text { isoform } 1 \text {; } \\
\text { F-box and leucine-rich repeat protein } 5 \text { isoform } 2\end{array}$ & Proteolysis and peptidolysis \\
\hline 2.62 & $\begin{array}{l}\text { CEBPD; CELF; } \\
\text { CRP3; C/EBP-delta; } \\
\text { NF-IL6-beta }\end{array}$ & S63168 & CCAAT/enhancer binding protein delta & Regulation of transcription \\
\hline 2.61 & C6orf37 & NM_017633 & Chromosome 6 open reading frame 37 & Unknown function \\
\hline 2.61 & ADD3 & D67031 & Adducin 3 isoform a; adducin 3 isoform b & Cytoskeleton \\
\hline 2.58 & NRD1 & X93207 & Nardilysin & Cell proliferation \\
\hline 2.58 & RAI1 & NM_017574 & $\begin{array}{l}\text { Retinoic acid induced } 1 \text { isoform } 1 \text {; retinoic acid induced } 1 \\
\text { isoform } 3 \text {; retinoic acid induced } 1 \text { isoform } 2\end{array}$ & Unknown function \\
\hline 2.58 & PTK2 & NM_005607 & $\begin{array}{l}\text { PTK2 protein tyrosine kinase } 2 \text { isoform b; PTK2 protein tyrosine } \\
\text { kinase } 2 \text { isoform a }\end{array}$ & Cell adhesion \\
\hline 2.57 & FLJ10496 & NM_018114 & Hypothetical protein FLJ10496 & Unknown function \\
\hline 2.57 & MGC2744 & NM_025267 & Hypothetical protein MGC2744 & Unknown function \\
\hline 2.56 & & & & Retired \\
\hline 2.55 & NICE-4 & D63478 & NICE-4 protein & Regulation of transcription \\
\hline 2.52 & RPL23AP7 & ВC000596 & RPL23AP7 protein & Development \\
\hline 2.49 & PEX14 & ВC006327 & Peroxisomal biogenesis factor 14 & Metabolism \\
\hline 2.49 & NPEPPS & AJ132583 & Aminopeptidase puromycin sensitive & Proteolysis and peptidolysis \\
\hline 2.48 & PACE-1 & ВC014662 & Ezrin-binding partner PACE-1 isoform 1 & Unknown function \\
\hline 2.48 & & ВС047949 & Similar to expressed sequence AI426465 & Unknown function \\
\hline 2.46 & MGC26610 & NM_144647 & Hypothetical protein MGC26610 & Unknown function \\
\hline 2.45 & LTA4H & J03459 & Leukotriene A4 hydrolase & Proteolysis and peptidolysis \\
\hline 2.43 & XTP2 & NM_015172 & HBxAg transactivated protein 2 & Apoptosis \\
\hline
\end{tabular}


Supplementary Table II. Continued.

\begin{tabular}{|c|c|c|c|c|}
\hline $\begin{array}{l}\text { Fold } \\
\text { change }\end{array}$ & Common & GenBank & Product & GO biological process \\
\hline 2.43 & EPHX2 & ВC011628 & Epoxide hydrolase 2, cytoplasmic & Defense response \\
\hline 2.43 & UACA & NM_018003 & Uveal autoantigen with coiled-coil domains and ankyrin repeats & Unknown function \\
\hline 2.43 & MTA3 & ВC004227 & MTA3 protein & Regulation of transcription \\
\hline 2.42 & NCOA6 & AF171667 & Nuclear receptor coactivator 6 & Regulation of transcription \\
\hline 2.41 & NACA & AK090650 & Nascent-polypeptide-associated complex alpha polypeptide & Protein biosynthesis \\
\hline 2.40 & JWA & ВC005143 & Cytoskeleton related vitamin A responsive protein & Metabolism \\
\hline 2.40 & FLJ20531 & NM_017865 & Hypothetical protein FLJ20531 & Unknown function \\
\hline 2.38 & MRP63 & ВC023616 & Mitochondrial ribosomal protein 63 & Protein biosynthesis \\
\hline 2.38 & MRPS27 & NM_015084 & Mitochondrial ribosomal protein S27 & Protein biosynthesis \\
\hline 2.37 & LASS2 & NM_013384 & $\begin{array}{l}\text { LAG1 longevity assurance homolog } 2 \text { isoform 2; LAG1 } \\
\text { longevity assurance homolog } 2 \text { isoform } 1\end{array}$ & Metabolism \\
\hline 2.37 & DARS & NM_001349 & Aspartyl-tRNA synthetase & Protein biosynthesis \\
\hline 2.35 & STHM & U14550 & Sialyltransferase & Protein glycosylation \\
\hline 2.34 & $\mathrm{CN} 2$ & AK001692 & Cytosolic nonspecific dipeptidase (EC 3.4.13.18) & Proteolysis and peptidolysis \\
\hline 2.33 & SFRS2IP & AF030234 & Splicing factor, arginine/serine-rich 2 , interacting protein & mRNA processing \\
\hline 2.29 & RPL23A & ВC014459 & Ribosomal protein L23a & Protein biosynthesis \\
\hline 2.25 & FLJ22955 & ВC018132 & Hypothetical protein FLJ22955 & Unknown function \\
\hline 2.23 & OS-9 & U41635 & Amplified in osteosarcoma & Cell proliferation \\
\hline 2.23 & MRPL45 & NM_032351 & Mitochondrial ribosomal protein L45 & Protein biosynthesis \\
\hline 2.23 & SPPL3 & NM_139015 & SPPL3 protein & Unknown function \\
\hline 2.21 & TCEA2 & ВC018896 & $\begin{array}{l}\text { Transcription elongation factor A protein } 2 \text { isoform a; } \\
\text { transcription elongation factor A protein } 2 \text { isoform b }\end{array}$ & Regulation of transcription \\
\hline 2.20 & ZNF281 & NM_012482 & Zinc finger protein 281 & Regulation of transcription \\
\hline 2.16 & SUPT5H & Y12790 & Suppressor of Ty 5 homolog & Regulation of transcription \\
\hline 2.16 & FDXR & NM_004110 & $\begin{array}{l}\text { Ferredoxin reductase isoform } 2 \text { precursor; ferredoxin } \\
\text { reductase isoform } 1 \text { precursor }\end{array}$ & Metabolism \\
\hline 2.14 & ELAC2 & ВС001939 & elaC homolog 2 & mRNA processing \\
\hline 2.11 & EIF4A1 & ВC009585 & Eukaryotic translation initiation factor $4 \mathrm{~A}$, isoform 1 & Regulation of translation \\
\hline 2.10 & MTATP8 & NM_173703 & ATP synthase 8 & Ion transport \\
\hline 2.10 & PIK4CB & NM_002651 & Phosphatidylinositol 4-kinase, catalytic, beta polypeptide & Signal transduction \\
\hline 2.08 & & NM_024521 & & Unknown function \\
\hline 2.07 & LOC90522 & ВC007644 & $\begin{array}{l}\text { Similar to putative transmembrane protein; homolog of } \\
\text { yeast Golgi membrane protein Yiflp (Yiplp-interacting factor) }\end{array}$ & Unknown function \\
\hline 2.06 & SDBCAG84 & NM_015966 & $\begin{array}{l}\text { Serologically defined breast cancer antigen } 84 \text { isoform b; } \\
\text { serologically defined breast cancer antigen } 84 \text { isoform a }\end{array}$ & Breast cancer antigen \\
\hline 2.06 & MGC2491 & ВC000262 & Hypothetical protein MGC2491 & Unknown function \\
\hline 2.04 & USP11 & NM_004651 & Ubiquitin specific protease 11 & $\begin{array}{l}\text { Protein catabolism; } \\
\text { ubiquitin cycle }\end{array}$ \\
\hline 2.03 & PPP1CC & X74008 & Protein phosphatase 1 , catalytic subunit, gamma isoform & Metabolism \\
\hline 2.03 & RBMX & ВС006550 & RNA binding motif protein, $\mathrm{X}$ chromosome & Regulation of transcription \\
\hline 2.03 & PRC & AF325193 & PGC-1 related co-activator & Unknown function \\
\hline 2.03 & FLJ20315 & NM_017763 & Hypothetical protein FLJ20315 & Regulation of transcription \\
\hline 2.03 & LOC284361 & AY194293 & Hypothetical protein LOC284361 & Unknown function \\
\hline-2.00 & GPD1 & NM_005276 & Glycerol-3-phosphate dehydrogenase 1 (soluble) & Metabolism \\
\hline-2.00 & & & & Unknown function \\
\hline-2.02 & CBRC7TM_519 & AB065956 & Seven transmembrane helix receptor & Signal transduction \\
\hline-2.03 & FLJ36666 & NM_152482 & Hypothetical protein FLJ36666 & Unknown function \\
\hline-2.04 & PIASY & AF077952 & Protein inhibitor of activated STAT protein PIASy & Regulation of transcription \\
\hline-2.04 & SLC12A7 & AF105365 & $\begin{array}{l}\text { Solute carrier family } 12 \text { (potassium/chloride transporters), } \\
\text { member } 7\end{array}$ & Ion transport \\
\hline-2.06 & $\begin{array}{l}\text { DRD1; DADR; } \\
\text { DRD1A }\end{array}$ & S58541 & Dopamine receptor D1 & Signal transduction \\
\hline
\end{tabular}


Supplementary Table II. Continued.

\begin{tabular}{|c|c|c|c|c|}
\hline $\begin{array}{l}\text { Fold } \\
\text { change }\end{array}$ & Common & GenBank & Product & GO biological process \\
\hline-2.06 & LILRB4 & ВC026309 & $\begin{array}{l}\text { Leukocyte immunoglobulin-like receptor, subfamily B } \\
\text { (with TM and ITIM domains), member } 4\end{array}$ & Immune response \\
\hline-2.06 & FLJ22202 & NM_024883 & Hypothetical protein FLJ22202 & Unknown function \\
\hline-2.07 & DKFZp434L192 & NM_152746 & Hypothetical protein DKFZp434L192 & Unknown function \\
\hline-2.08 & FN5 & NM_020179 & FN5 protein & Unknown function \\
\hline-2.12 & $\begin{array}{l}\text { NEF3; NFM; } \\
\text { NEFM; NF-M }\end{array}$ & Y00067 & Neurofilament 3 (150kDa medium) & Cytoskeleton \\
\hline-2.15 & SERPINB2 & Y00630 & $\begin{array}{l}\text { Serine (or cysteine) proteinase inhibitor, clade B (ovalbumin), } \\
\text { member } 2\end{array}$ & Anti-apoptosis \\
\hline-2.15 & & & & Retired \\
\hline-2.16 & $\mathrm{COH} 1$ & NM_017890 & $\begin{array}{l}\text { Cohen syndrome } 1 \text { protein isoform } 3 \text {; Cohen syndrome } 1 \text { protein } \\
\text { isoform } 5 \text {; Cohen syndrome } 1 \text { protein isoform } 1 \text {; Cohen syndrome } 1 \\
\text { protein isoform } 4 \text {; Cohen syndrome } 1 \text { protein isoform } 2\end{array}$ & Transport \\
\hline-2.19 & IGF2AS & NM_016412 & Insulin-like growth factor 2 , antisense & Regulation of transcription \\
\hline-2.20 & PIPPIN & NM_014460 & RNA-binding protein pippin & mRNA processing \\
\hline-2.20 & LOC90139 & AK027715 & Tetraspanin similiar to uroplakin 1 & Signal transduction \\
\hline-2.20 & BAIAP1 & AB010894 & BAI1-associated protein 1 & Cell adhesion \\
\hline-2.20 & JDP2 & NM_130469 & Jun dimerization protein & Regulation of transcription \\
\hline-2.21 & GYG2 & U94362 & Glycogenin 2 & Metabolism \\
\hline-2.21 & MGC40084 & NM_152769 & Hypothetical protein MGC40084 & Unknown function \\
\hline-2.23 & SIAT8A & NM_003034 & Sialyltransferase $8 \mathrm{~A}$ & Metabolism \\
\hline-2.23 & NPPC & NM_024409 & Natriuretic peptide precursor $\mathrm{C}$ & Regulation of transcription \\
\hline-2.27 & COXVIB2 & NM_144613 & Cytochrome c oxidase subunit VIb, testis-specific isoform & Regulation of transcription \\
\hline-2.27 & & & & Unknown function \\
\hline-2.28 & $\mathrm{DPT}$ & ВC033736 & Dermatopontin precursor & Cell adhesion \\
\hline-2.28 & DKFZp434C0923 & NM_017598 & Hypothetical protein DKFZp434C0923 & Unknown function \\
\hline-2.28 & LY86 & ВC038846 & MD-1, RP105-associated & Inflammatory response \\
\hline-2.30 & CBRC7TM_2 & AB065439 & Seven transmembrane helix receptor & Signal transduction \\
\hline-2.30 & KIAA0937 & AK074166 & FLJ00239 protein & Unknown function \\
\hline-2.31 & ORM1 & ВC015964 & Orosomucoid 2 & Transport \\
\hline-2.31 & HIPK2 & AF208291 & Homeodomain interacting protein kinase 2 & Transcription co-repressor \\
\hline-2.31 & KIAA1201 & AB033027 & KIAA1201 protein & Unknown function \\
\hline-2.32 & CD163 & NM_004244 & CD163 antigen & Retired \\
\hline-2.33 & ABR & U01147 & $\begin{array}{l}\text { Active breakpoint cluster region-related protein isoform b; } \\
\text { active breakpoint cluster region-related protein isoform a }\end{array}$ & Signal transduction \\
\hline-2.33 & TRPV5 & AF304464 & Transient receptor potential cation channel, subfamily V, member 5 & Signal transduction \\
\hline-2.33 & & & & Unknown function \\
\hline-2.35 & GJB4 & NM_153212 & Gap junction protein, beta 4 & Cell communication \\
\hline-2.36 & NRXN2 & AB035266 & $\begin{array}{l}\text { Neurexin } 2 \text { isoform alpha-1 precursor; neurexin } 2 \text { isoform alpha- } 2 \\
\text { precursor; neurexin } 2 \text { isoform beta precursor }\end{array}$ & Cell adhesion \\
\hline-2.38 & STK10 & AB015718 & Serine/threonine kinase 10 & Protein phosphorylation \\
\hline-2.39 & FBXW8 & NM_153348 & $\begin{array}{l}\text { F-box and WD- } 40 \text { domain protein } 8 \text { isoform } 2 \text {; F-box and } \\
\text { WD-40 domain protein } 8 \text { isoform } 1\end{array}$ & Protein catabolism \\
\hline-2.40 & FLT3LG & NM_001459 & Fms-related tyrosine kinase 3 ligand & Signal transduction \\
\hline-2.42 & & & & Retired \\
\hline-2.42 & RAB6B & AF166492 & RAB6B, member RAS oncogene family & Signal transduction \\
\hline-2.43 & NRN1 & ВС042019 & Neuritin precursor & Neuritogenesis \\
\hline-2.44 & ARHGAP9 & ВC006107 & Rho GTPase activating protein 9 & Cell adhesion \\
\hline-2.44 & SPTBN4 & AF082075 & Spectrin, beta, non-erythrocytic 4 & Cytoskeleton \\
\hline-2.44 & GNA12 & AF493901 & Guanine nucleotide binding protein (G protein) alpha 12 & Signal transduction \\
\hline-2.44 & MT1X & ВC032338 & Metallothionein 1X & Response to metal ion \\
\hline
\end{tabular}


Supplementary Table II. Continued.

\begin{tabular}{|c|c|c|c|c|}
\hline $\begin{array}{l}\text { Fold } \\
\text { change }\end{array}$ & Common & GenBank & Product & GO biological process \\
\hline-2.45 & EDG6 & ВC014970 & Endothelial differentiation, $\mathrm{G}$ protein coupled receptor 6 precursor & Immune response \\
\hline-2.47 & MGC33486 & NM_153266 & Hypothetical protein MGC33486 & Unknown function \\
\hline-2.48 & MGC4645 & NM_024515 & Hypothetical protein MGC4645 & Retired \\
\hline-2.51 & ZMYND15 & NM_032265 & Zinc finger, MYND domain containing 15 & Unknown function \\
\hline-2.53 & SLA & U44403 & Src-like-adaptor & Signal transduction \\
\hline-2.62 & MGC10986 & AK092301 & Hypothetical protein MGC10986 & Electron transport \\
\hline-2.62 & HEM1 & NM_005337 & Hematopoietic protein 1 & Hematopoietic differentiation \\
\hline-2.73 & SRRM2 & AB016092 & Splicing coactivator subunit SRm300 & mRNA splicing \\
\hline-2.73 & FLJ12587 & AK092231 & Hypothetical protein FLJ12587 & Unknown function \\
\hline-2.75 & HIST1H3F & NM_021018 & H3 histone family, member I & Chromosome organization \\
\hline-2.75 & SPATA11 & ВC004393 & Spermatogenesis associated 11 & Unknown function \\
\hline-2.78 & C7orf10 & NM_024728 & Chromosome 7 open reading frame 10 & Unknown function \\
\hline-2.79 & THY1 & AK057865 & Thy- 1 cell surface antigen & Immune response \\
\hline-2.81 & ATSV & NM_138483 & Axonal transport of synaptic vesicles & Unknown function \\
\hline-2.82 & CSPG2 & NM_004385 & Chondroitin sulfate proteoglycan 2 (versican) & Cell adhesion \\
\hline-2.88 & FLJ11017 & ВC037906 & Hypothetical protein FLJ11017 & Unknown function \\
\hline-2.89 & HCST & AL050163 & DNAX-activation protein 10 & Immune response \\
\hline-2.89 & DPF3 & AK024141 & Cer-d4 (mouse) homolog & Regulation of transcription \\
\hline-2.93 & LIMR & AF260728 & Lipocalin-interacting membrane receptor & Inflammatory response \\
\hline-2.94 & HOXB8 & NM_024016 & Homeo box B8 & Regulation of transcription \\
\hline-3.01 & LOC150236 & & & Unknown function \\
\hline-3.03 & ZNF358 & NM_018083 & Zinc finger protein 358 & Regulation of transcription \\
\hline-3.04 & QSCN6 & NM_152662 & Hypothetical protein FLJ23867 & Unknown function \\
\hline-3.07 & EVX1 & NM_001989 & Even-skipped homeo box 1 & Regulation of transcription \\
\hline-3.09 & KIAA0469 & NM_014851 & KIAA0469 gene product & Unknown function \\
\hline-3.10 & TP53TG3 & NM_015369 & TP53TG3 protein; TP53TG3a protein & p53 target gene \\
\hline-3.12 & NTNG2 & NM_032536 & Netrin G2 & Signal transduction \\
\hline-3.12 & TRAPPC3 & ВC007662 & BET3 homolog & Transport \\
\hline-3.13 & ADAMTS7 & AF140675 & $\begin{array}{l}\text { A disintegrin and metalloprotease with thrombospondin motifs- } 7 \\
\text { preproprotein }\end{array}$ & Cell invasion, metastasis \\
\hline-3.13 & TNFRSF4 & X75962 & OX40 homologue & Immune response \\
\hline-3.14 & & Z79611 & & Proteolysis and peptidolysis \\
\hline-3.21 & GALGT & M83651 & $\begin{array}{l}\text { UDP-N-acetyl-alpha-D-galactosamine:(N-acetylneuraminyl)- } \\
\text { galactosylglucosylceramide } \mathrm{N} \text {-acetylgalactosaminyltransferase }\end{array}$ & Metabolism \\
\hline-3.26 & SKIV2L & U09877 & Superkiller viralicidic activity 2-like homolog & Regulation of translation \\
\hline-3.28 & POU2F2 & M36653 & & Regulation of transcription \\
\hline-3.30 & HOXA3 & NM_030661 & Homeobox A3 protein isoform a; homeobox A3 protein isoform $b$ & Regulation of transcription \\
\hline-3.38 & FOXA3 & ВC016024 & Forkhead box A3 & Regulation of transcription \\
\hline-3.39 & $\mathrm{MEF} 2 \mathrm{C}$ & NM_002397 & $\begin{array}{l}\text { MADS box transcription enhancer factor 2, polypeptide C } \\
\text { (myocyte enhancer factor } 2 \mathrm{C} \text { ) }\end{array}$ & Development \\
\hline-3.39 & GMFG & ВC032819 & Glia maturation factor, gamma & Protein phosphorylation \\
\hline-3.41 & NOVA2 & NM_002516 & Neuro-oncological ventral antigen 2 & Oncogene \\
\hline-3.53 & LOC90353 & NM_145232 & LOC90353 & Electron transport \\
\hline-3.58 & STK17A & ВC047696 & Serine/threonine kinase 17a (apoptosis-inducing) & Apoptosis \\
\hline-3.61 & MYOD1 & NM_002478 & Myogenic factor 3 & Development \\
\hline-3.68 & CPNE7 & AJ133798 & Copine 7 isoform b; copine 7 isoform a & Metabolism \\
\hline-3.69 & C14orf169 & NM_024644 & Chromosome 14 open reading frame 169 & Unknown function \\
\hline-3.72 & GRIN1 & NM_007327 & $\begin{array}{l}\text { NMDA receptor } 1 \text { isoform NR1-1 precursor; NMDA receptor } 1 \text { isoform } \\
\text { NR1-3 precursor; NMDA receptor } 1 \text { isoform NR1-2 precursor }\end{array}$ & Signal transduction \\
\hline-3.73 & GRIN1 & NM_021569 & $\begin{array}{l}\text { NMDA receptor } 1 \text { isoform NR1-1 precursor; NMDA receptor } 1 \\
\text { isoform NR1-3 precursor; NMDA receptor } 1 \text { isoform NR1-2 precursor }\end{array}$ & Signal transduction \\
\hline
\end{tabular}


Supplementary Table II. Continued.

\begin{tabular}{|c|c|c|c|c|}
\hline $\begin{array}{l}\text { Fold } \\
\text { change }\end{array}$ & Common & GenBank & Product & GO biological process \\
\hline-3.80 & $\mathrm{H} 2 \mathrm{AFB}$ & AF254576 & $\mathrm{H} 2 \mathrm{~A}-\mathrm{Bbd}$ & Chromosome organization \\
\hline-3.89 & GPR7 & U22491 & G protein-coupled receptor 7 & Signal transduction \\
\hline-3.91 & $\mathrm{HCN} 2$ & NM_001194 & Hyperpolarization activated cyclic nucleotide-gated potassium channel 2 & Ion transport \\
\hline-3.98 & SRP & NM_033199 & Stresscopin-related peptide & Response to stress \\
\hline-4.03 & FOXC2 & NM_005251 & Forkhead box $\mathrm{C} 2$ & Development \\
\hline-4.10 & FLJ14464 & NM_032789 & Hypothetical protein FLJ14464 & Unknown function \\
\hline-4.13 & FXR2 & ВC020090 & Fragile X mental retardation syndrome related protein 2 & Regulation of transcription \\
\hline-4.13 & GALR3 & AF073799 & Galanin receptor 3 & Signal transduction \\
\hline-4.15 & FLJ36874 & NM_152716 & Hypothetical protein FLJ36874 & Unknown function \\
\hline-4.17 & HEYL & ВC006087 & Hairy/enhancer-of-split related with YRPW motif-like & Regulation of transcription \\
\hline-4.26 & ACP5 & $\mathrm{BC} 025414$ & Tartrate resistant acid phosphatase 5 precursor & Protein dephosphorylation \\
\hline-4.27 & UPK3B & NM_030570 & Uroplakin 3B isoform a; uroplakin 3B isoform c; uroplakin 3B isoform b & Metastasis \\
\hline-4.27 & SOLH & NM_005632 & Small optic lobes homolog & Proteolysis and peptidolysis \\
\hline-4.27 & FLJ90805 & AK075286 & Hypothetical protein FLJ90805 & Unknown function \\
\hline-4.29 & & & & Unknown function \\
\hline-4.31 & $\mathrm{RBP} 4$ & ВC020633 & Retinol-binding protein 4 , plasma precursor & Metabolism \\
\hline-4.37 & BAG5 & AF095195 & BCL2-associated athanogene 5 & Apoptosis \\
\hline-4.37 & IGHM & L01278 & & Immune response \\
\hline-4.55 & GLTSCR1 & NM_015711 & Glioma tumor suppressor candidate region gene 1 & Tumor supressor \\
\hline-4.59 & PADI4 & AB017919 & Peptidyl arginine deiminase, type IV & Protein modification \\
\hline-4.61 & CXCL14 & BC003513 & Small inducible cytokine B14 precursor & Inflammatory response \\
\hline-4.74 & CAM-KIIN & NM_033259 & CaM-KII inhibitory protein & Cell growth \\
\hline-4.78 & C15orf16 & NM_130901 & Chromosome 15 open reading frame 16 & Unknown function \\
\hline-4.81 & CACNG6 & AF361352 & $\begin{array}{l}\text { Voltage-dependent calcium channel gamma- } 6 \text { subunit isoform c; } \\
\text { voltage-dependent calcium channel gamma- } 6 \text { subunit isoform a; } \\
\text { voltage-dependent calcium channel gamma- } 6 \text { subunit isoform b }\end{array}$ & Ion transport \\
\hline-4.83 & EVX1 & X60655 & Even-skipped homeo box 1 & Regulation of transcription \\
\hline-4.93 & DUSP9 & Y08302 & Dual specificity phosphatase 9 & Protein dephosphorilation \\
\hline-5.03 & MGC27165 & S55736 & & Unknown function \\
\hline-5.03 & FLJ22184 & NM_025094 & & Unknown function \\
\hline-5.08 & C21orf56 & AL136871 & Chromosome 21 open reading frame 56 & Unknown function \\
\hline-5.18 & COL3A1 & $\mathrm{X} 14420$ & Alpha 1 type III collagen & Cell adhesion \\
\hline-5.21 & PTP4A3 & ВC003105 & $\begin{array}{l}\text { Protein tyrosine phosphatase type IVA, member } 3 \text { isoform } 2 \text {; } \\
\text { protein tyrosine phosphatase type IVA, member } 3 \text { isoform } 1\end{array}$ & Protein dephosphorylation \\
\hline-5.26 & FLJ22795 & AF316855 & Hypothetical protein FLJ22795 & Unknown function \\
\hline-5.38 & DOK4 & ВC003541 & Downstream of tyrosine kinase 4 & Signal transduction \\
\hline-5.46 & & & & Retired \\
\hline-5.52 & CASKIN1 & AF451977 & CASK interacting protein 1 & Chromosome organization \\
\hline-5.56 & & & & Unknown function \\
\hline-5.62 & $\begin{array}{l}\text { GPR14; UTR; } \\
\text { UTR2 }\end{array}$ & AF140631 & G protein-coupled receptor 14 & Signal transduction \\
\hline-5.62 & LOC 255783 & NM_178511 & Hypothetical protein LOC255783 & Unknown function \\
\hline-5.62 & MECT1 & NM_025021 & Mucoepidermoid carcinoma translocated 1 & Unknown function \\
\hline-5.65 & CREBL1 & NM_004381 & cAMP responsive element binding protein-like 1 & Regulation of transcription \\
\hline-5.78 & LRP6 & NM_002336 & Low density lipoprotein receptor-related protein 6 & Metabolism \\
\hline-5.81 & CBX6 & ВC012111 & Chromobox homolog 6 & Chromosome organization \\
\hline-5.99 & $\begin{array}{l}\text { FOXD3; HFH2; } \\
\text { Genesis }\end{array}$ & AF197560 & Forkhead box D3 & Development \\
\hline-6.21 & DUX4 & NM_033178 & Double homeobox, 4 & Development \\
\hline-6.67 & LOC90313 & AK075341 & Hypothetical protein $\mathrm{BC} 004507$ & Unknown function \\
\hline-7.14 & SYMPK & ВC006536 & Symplekin & mRNA processing \\
\hline-7.63 & WNT10A & AK024363 & Wingless-type MMTV integration site family, member 10A precursor & Development \\
\hline
\end{tabular}

